\title{
FACEBOOK MEETS THE NLRB: EMPLOYEE ONLINE COMMUNICATIONS AND UNFAIR LABOR PRACTICES
}

\author{
Robert Sprague*
}

\begin{abstract}
In the past eighteen months, the National Labor Relations Board ("NLRB") has received approximately one hundred charges from employees that were disciplined or fired as a result of their work-related online communications, principally through Facebook. These and other charges have resulted in twenty-one NLRB Office of the General Counsel Advice Memoranda, ten General Counsel reviews, four Administrative Law Judge ("ALJ") decisions, and one Board decision, all addressing employee use of social media. This Article is the first to examine in detail those employee charges and the thirty-six incidents addressed by the Office of the General Counsel, the ALJs, and the Board. This Article's analysis reveals that, based on these charges and incidents, most employees are not engaging online in concerted activities protected by the National Labor Relations Act. Rather, for the most part, they are griping about work and getting fired for it. However, these charges and incidents have raised concerns over the enforcement of overly broad social media policies by employers. Most importantly, the nature of social media technologies raises new issues of unlawful employer surveillance that have yet to be directly addressed by the NLRB. These three issues are examined through this article: determining when employee online communications are protected concerted activity, determining what constitutes an acceptable social media policy, and determining when an employer might engage in unlawful online surveillance.
\end{abstract}

* J.D., M.B.A. Associate Professor of Legal Studies in Business, University of Wyoming College of Business. The author thanks Abigail Fournier, J.D. 2013, University of Wyoming College of Law, for her superb assistance in analyzing the NLRB documents referenced in this Article. 


\section{INTRODUCTION}

With the continued growth of social media platforms, it was inevitable that employees would voice their complaints about work online. Employers may be inclined to discipline or even fire employees due to online postings critical of the workplace. If, however, those online postings constitute protected concerted activity, the National Labor Relations Act ("NLRA" or "Act") may prevent employers from taking any disciplinary action. Between June 2009 and April 2011, the National Labor Relations Board ("NLRB") received approximately one hundred charges from employees that were disciplined or fired due to online postings, primarily on Facebook. Since late 2010, the NLRB has addressed thirty-six situations involving employee online postings and employer social media policies. This Article examines the analyses underlying thirty-two of those incidents, highlighting situations in which employee online postings can constitute concerted activity protected under federal law.

To establish the foundation for the forthcoming analyses, this Article first provides an overview of what constitutes protected concerted activity under section 7 of the NLRA. This Article then examines twenty-one NLRB Office of the General Counsel Memoranda, seven additional General Counsel reviews, four Administrative Law Judge ("ALJ") decisions, and one Board decision. ${ }^{2}$ Application of these conclusions and decisions are then applied in the context of employees complaining about work online, primarily on Facebook. Three issues are examined in detail: (1) exactly when an employee is engaged in protected concerted activity when complaining online about work; (2) what is expected of employers in fashioning social media policies so as to not unlawfully inhibit employee concerted activities; and, (3) what subtleties lurk in the Facebook age with regard to employer surveillance of employee online activities.

\section{SECTION 7 PROTECTED CONCERTED ACTIVITY}

Section 7 of the NLRA protects concerted activity: It guarantees employees the right to "engage in ... concerted activities for the purpose of ... mutual aid or protection." Section 7 is enforced by section 8(a)(1) of the NLRA, which makes it an unfair labor practice for an employer to

1. 29 U.S.C. $\S \S 151-169$ (2006).

2. Within this Article, activities by the NLRB generally, such as memoranda from the Office of the General Counsel, will be identified with "NLRB." Decisions by the NLRB's (usually) five-member quasi-judicial body will be identified as being by the "Board."

3. 29 U.S.C. $\S 157$ (2006). 
"interfere with, restrain, or coerce employees in the exercise of the rights guaranteed in section 157 of this title [section 7 of the NLRA]."

The term "concerted activities" is not defined by the NLRA and has been the subject of challenging interpretations and debate. ${ }^{5}$ In one of the first interpretations of that term, the U.S. Supreme Court held that when seven employees had, after numerous complaints, walked off the job because their machine shop was too cold, they had engaged in protected concerted activity. ${ }^{6}$ The Court concluded the workers' walkout served as a means for the "workers to act together to better their working conditions.", The Court also noted that the workers' section 7 rights were especially important in this case because they were "wholly unorganized;" "[t]hey had no bargaining representative and, in fact, no representative of any kind to present their grievances to their employer. Under these circumstances, they had to speak for themselves as best they could." " This language has subsequently been used to confirm that section 7 rights apply to nonunion workplaces, ${ }^{9}$ particularly since those workers have no designated bargaining representative. ${ }^{10}$

The NLRB, which enforces section $7,{ }^{11}$ articulated its approach to concerted activity in an August 2011 Advice Memorandum from the Office

4. Id. $\S 158(\mathrm{a})(1)$.

5. See Calvin William Sharpe, "By Any Means Necessary"-Unprotected Conduct and Decisional Discretion Under the National Labor Relations Act, 20 BERKELEY J. EMP. \& LAB. L. 203, 204 (1999) ("The issue of how far unorganized and organized employees can go in pressing legitimate claims has been controversial since the inception of the... NLRA."); see also Robert A. Gorman \& Matthew W. Finkin, BASIC TEXT ON LABOR LAW: Unionization AND COLlective BARGaining 396 (2d ed. 2004) ("Whether employee activity falls within or without the shelter of section 7 is . . . a definitional issue of utmost importance in the administration of the Act.").

6. NLRB v. Wash. Aluminum Co., 370 U.S. 9, 14-18 (1962).

7. Id. at 14 .

8. Id.

9. See William R. Corbett, Waiting for the Labor Law of the Twenty-First Century: Everything Old Is New Again, 23 BERKELEY J. EMP. \& LAB. L. 259, 278 (2002) (noting that section 7 rights are not limited to employees represented by a union) (citing In re Epilepsy Found. of Northeast Ohio, 331 N.L.R.B. 676 (2000), aff'd in part and rev'd in part sub nom. Epilepsy Found. of Northeast Ohio v. NLRB, 268 F.3d 1095 (D.C. Cir. 2001), cert. denied, 536 U.S. 904 (2002)).

10. See Citizens Inv. Servs. Corp. v. NLRB, 430 F.3d 1195, 1197 (D.C. Cir. 2005) (citing Wash. Aluminum Co., 370 U.S. at 14). Charles Morris has argued that while section 7 clearly applies in a nonunion setting, Congress intended it to apply to pre-organizational activity-i.e., activity precursory to formal union organization. Charles J. Morris, NLRB Protection in the Nonunion Workplace: A Glimpse at a General Theory of Section 7 Conduct, 137 U. PA. L. REV. 1673, 1751 (1989). Morris further argues that the NLRB and the courts should emphasize the strong nexus between traditional union activity and mutualaid-or-protection concerted activity to vindicate not only employment rights of individual employees, but particularly public rights expressed by the NLRA. Id. at 1751-52.

11. See generally 29 C.F.R. $\S \S 101.1-101.43$ (2011) (providing the procedures used in investigating and prosecuting unfair labor practices). 
of the General Counsel: "An individual's activity is concerted when the individual acts "with or on the authority of other employees, and not solely by and on behalf of the employee himself.",12 In addition, "individual activities that are the logical outgrowth of concerns expressed by the employees collectively are considered concerted." ${ }^{\prime 3}$ The Board has also determined that "employee discussions related to shared concerns about terms and conditions of employment constitute concerted activity even if no specific group action is contemplated ...."14 In contrast, "comments made solely by and on behalf of the employee himself are not concerted." 15 Finally, in order for the concerted activity to be protected, it must relate to working conditions. ${ }^{16}$ In sum, "Congress conceived protected concerted activity as a guarantee of the right of workers to organize and express themselves freely . . . concerning their wages and working conditions.",17

\section{Social Media Postings as Protected Concerted Activity}

While workers being fired or disciplined as a result of their online postings is not a new phenomenon, ${ }^{18}$ such incidents had rarely been

12. Advice Memorandum from the NLRB Office of the Gen. Counsel to Cornele A. Overstreet, Regional Director of Region 28, Sagepoint Financial, Inc., No. 28-CA-23441, 2011 WL 3793672, at*2 (Aug. 9, 2011) [hereinafter Sagepoint Fin. Adv. Mem.], available at http://mynlrb.nlrb.gov/link/document.aspx/09031d45805fa7fd (citing Meyers Indus., 268 N.L.R.B. 493, 497 (1984) (Meyers I), rev'd sub nom. Prill v. NLRB, 755 F.2d 941 (D.C. Cir.), cert. denied, 474 U.S. 948 (1985), on remand Meyers Indus., 281 N.L.R.B. 882, 885 (1986) (Meyers II), aff'd sub nom. Prill v. NLRB, 835 F.2d 1481 (D.C. Cir. 1987), cert. denied, 487 U.S. 1205 (1988)); see also Hispanics United of Buffalo, Inc., Docket No. 3CA-27872, 2011 WL 3894520, at 7 (N.L.R.B. Div. of Judges Sept. 2, 2011), available at http://mynlrb.nlrb.gov/link/document.aspx/ 09031d4580622877 (pagination based on NLRB-source document). See infra note 29 (discussing Advice Memoranda).

13. Sagepoint Fin. Adv. Mem., supra note 12, at *2 (internal quotation marks omitted).

14. Sagepoint Fin. Adv. Mem., supra note 12, at $* 2$ (internal quotation marks omitted) (citing St. Margaret Mercy Healthcare Ctrs., 350 N.L.R.B. 203, 212 (2007), enforced sub nom. St. Margaret Mercy Healthcare Ctrs., v. NLRB, 519 F.3d 373 (7th Cir. 2008)).

15. Sagepoint Fin. Adv. Mem., supra note 12, at *3 (internal quotation marks omitted) (citing Meyers I, 268 N.L.R.B. at 497).

16. See, e.g., Advice Memorandum from the NLRB Office of the Gen. Counsel to Richard L. Ahearn, Regional Director of Region 19, The Wedge Corp. d/b/a/ The Rock Wood Fired Pizza \& Spirits, No. 19-CA-32981, 2011 WL 4526829, at *3 (Sept. 19, 2011) [hereinafter Rock Wood Adv. Mem.], available at http://mynlrb.nlrb.gov/link/document .aspx/09031d4580681027 ("[W]hen employees engage in conduct to address the job performance of their coworkers or supervisor that adversely impacts their working conditions, their activity is protected.").

17. Morris, supra note 10, at 1684. See infra Part III.A. (analyzing further the issue of protected concerted activity).

18. See, e.g., Robert Sprague, Fired for Blogging: Are There Legal Protections for Employees Who Blog?, 9 U. PA. J. LAB. \& EMP. L. 355, 357-58 (2007) (describing examples of employees fired as a result of materials they had published online); Marc Cote, Note, Getting Dooced: Employee Blogs and Employer Blogging Policies Under the National 
addressed by the NLRB. In Fall 2007, an employee-union representative was fired after posting a story on a union website critical of the employer's level of patient care. ${ }^{19}$ The Board determined the employee's comments were directly related to the impact of staffing levels on nurses' terms and conditions of employment. ${ }^{20}$ As such, the statements were a protected concerted activity. ${ }^{21}$

For the next two years, it did not appear there was much concern with whether employee online postings constituted protected concerted activity, ${ }^{22}$ at least not until November 2009, when Dawnmarie Souza was called into her supervisor's office. ${ }^{23}$ Souza, a paramedic employed by American Medical Response of Connecticut (“AMR"), was instructed by her supervisor to write an incident report concerning one of the calls she made on her shift, ostensibly because a complaint had been filed against her by the husband of a woman Souza had treated. Souza requested that a union representative be present before she would write the report. When

Labor Relations Act, 82 WASH. L. REV. 121, 122-23 (2007) (same). "Posting" refers to publishing material online, whether on a blog, on a Facebook "wall," or uploading a video to YouTube. In contrast, when one publishes a message using Twitter, the act is referred to as "tweeting" and the message is referred to as a "tweet."

19. Valley Hosp. Med. Ctr., Inc. \& Nevada Serv. Employees Union, Local 1107, Affiliated with Serv. Employees Int'l Union., 351 N.L.R.B. 1250 (2007), enforced sub nom. Nev. Serv. Emps. Union, Local 1107 v. NLRB, 358 F. App'x. 783 (9th Cir. 2009).

20. Id. at 1253 .

21. See id. at 1254; see also Amcast Auto. of Ind., 348 N.L.R.B. 836, 838 (2006) (deciding that an employee who had used a company computer during work hours to search the Internet for information regarding a company rumored to be purchasing the employer was not engaged in protected concerted activity, concluding "that the mere possibility of a future sale was too speculative and remote for [the employee's] Internet activity to be protected under Section 7"); Endicott Interconnect Tech., Inc., 345 N.L.R.B. 448, 451 (2005) (deciding that a posting by an employee on an internet forum critical of his employer was closely related to ongoing labor disputes and therefore protected under section 7), vacated sub nom. Endicott Interconnect Tech., Inc. v. N.L.R.B., 453 F.3d 532, 537 (D.C. Cir. 2006) (holding that the "disloyal, disparaging and injurious nature" of the employee's attacks on the company deprived him of protection under the Act). For a discussion of disloyalty, see Matthew W. Finkin, Disloyalty! Does Jefferson Standard Stalk Still?, 28 BERKELEY J. EMP. \& LAB. L. 541, 541 (2007) (arguing "that, at best, disloyalty is worthless as a guide to decision; at worst, it chills speech of social value, and ought to be abandoned").

22. Though it was the subject of scholarly discussion; see, e.g., Rafael Gely \& Leonard Bierman, Social Isolation and American Workers, Employee Blogging and Legal Reform, 20 HARV. J.L. \& TECH. 287 (2007); Katherine M. Scott, When Is Employee Blogging Protected by Section 7 of the NLRA?, 2006 DuKE L. \& TECH. REV. 17 (2006); Cote, supra note 18.

23. See Advice Memorandum from the NLRB Office of the Gen. Counsel to Jonathan B. Kreisberg, Regional Director of Region 34, American Medical Response of Connecticut, Inc., No. 34-CA-12576 at 3-5 (Oct. 5, 2010) [hereinafter AMR Adv. Mem.], available at http://mynlrb.nlrb.gov/link/document.aspx/09031d458055b9c4; see also Complaint and Notice of Hearing, Am. Med. Response of Conn., Inc., No. 34-CA-12576 (N.L.R.B. Oct. 27, 2010). 
her request was denied, she refused to write the report. Later that evening, Souza vented about the incident on her Facebook page, referring to her supervisor as a "17" (a term used for psychiatric patients), a "dick," and a "scumbag."." Souza was subsequently fired, in part, for posting derogatory remarks about her supervisor on Facebook. ${ }^{25}$

In fact, the NLRB began receiving complaints by employees, in the form of "charges," ${ }^{26}$ since at least June 2009; in all, the NLRB documented approximately one hundred charges of unfair labor practices arising from social media activities and policies between June 2009 and April 2011. ${ }^{27}$ While a majority of these charges have been closed with no action taken beyond, perhaps, a cursory investigation, ${ }^{28}$ the NLRB's Office of the General Counsel has published twenty-one Advise Memoranda and summarized ten additional situations, ${ }^{29}$ and four ALJ decisions and one

24. AMR Adv. Mem., supra note 23, at 3.

25. AMR Adv. Mem., supra note 23, at 5. For additional information regarding the Souza incident, see infra Part II.B.

26. The complaint process is initiated by an employee (individually or through representation) filing a charge with an NLRB Regional Office. See 29 C.F.R. $\S \S 101.1-$ 101.43 (detailing the filing and adjudication process). If the charge is determined to be of merit or not settled or not withdrawn, the NLRB will file a formal complaint. 29 C.F.R. $\S$ 101.8. If the complaint is not settled, it will be heard before an ALJ, 29 C.F.R. $\S 101.10$, whose decision is filed with the Board, 29 C.F.R. $\S 101.11$, which will either adopt, modify, or reject the findings and recommendations of the ALJ, 29 C.F.R. $\S 101.10,101.12$ (a). The Board's decision is subject to review by the federal circuit court of appeals. 29 C.F.R. $\S$ 101.14. The employee who files a charge is generically referred to as the "Charging Party."

27. The author submitted a Freedom of Information Act (FOIA) request to the NLRB seeking copies of "all charges, complaints, and completed settlements related to social media." In response, the NLRB sent a collection of documents, which included copies of 109 charges (ninety of which were filed by individual employees), nine complaints, and five settlement agreements. The documents were readily available since, by coincidence, the U.S. Chamber of Commerce had made an identical FOIA request just prior to the author's own request. See Michael J. Eastman, Exec. Dir. of Labor Law Policy, U.S. Chamber of Commerce, A Survey of Social Media Issues Before the NLRB 2 (Aug. 5, 2011), available at http://www.uschamber.com/sites/default/files/reports/NLRB $\% 20$ Social $\% 20 \mathrm{Media} \% 20$ Survey.pdf.

28. Through 2011, the majority of charges provided under the FOIA request had been officially closed, and for most of the closed cases, it is unknown what occurred between the filing of the original charge and the case being closed, i.e., the extent of any investigation, whether the NLRB Regional Office where the charge was filed concluded it was without merit, whether an informal agreement was reached between the employer and employee, or whether the employee abandoned or withdrew the charge.

29. In certain types of cases involving novel and complex issues, the NLRB Regional Director may be required to submit the case for advice from the NLRB's Office of the General Counsel before issuing a complaint. 29 C.F.R. $§ 101.8$. In April 2011, the Office of the General Counsel issued a memorandum requiring Regional Directors to submit for advice "[c]ases involving employer rules prohibiting, or discipline of employees for engaging in, protected concerted activity using social media, such as Facebook or Twitter." Memorandum from the NLRB Office of the Gen. Counsel to All Regional Directors, Officers-in-Charge, and Resident Officers, Mandatory Submissions to Advice, No. GC 11- 
Board decision have been issued. These thirty-six incidents provide excellent examples of the NLRB's application of facts to its own definition of protected concerted activity, as well as additional associated issues. The analysis underlying each of the incidents and their respective determinations is discussed below. ${ }^{30}$

\section{A. Threatening to Withhold Patient Care}

In June 2009, the senior management of a hospital became aware of Facebook postings by three employees in which one of the managers believed the employees were threatening to withhold care if they were personally offended by patients. ${ }^{31}$ The employees were suspended with pay pending a psychological exam, being formally advised their suspensions were due to "disparaging written comments made by you regarding patients and patient care that were brought to our attention., ${ }^{32}$ The employees were subsequently reinstated, though a memo was placed in each of their files stating they had violated an Employee Behavior Policy. ${ }^{33}$

In response to charges that the employer had engaged in unfair labor practices by disciplining the employees because of their Facebook postings, ${ }^{34}$ the NLRB's Office of the General Counsel concluded the Facebook postings suggested those employees might not provide appropriate care to the Employer's patients and did not constitute protected concerted activity. ${ }^{35}$ The employees also accused the employer of unlawful

11, 2011 WL 3348287, at *2 (Apr. 12, 2011), available at http://mynlrb.nlrb.gov/link/ document.aspx/09031d458047021e. Thirteen of the advice memoranda discussed in this Article, as well as all four ALJ decisions and the one Board decision, address charges that were included in the documents provided to this author by the NLRB. See supra note 27 for a discussion of the documents provided by the NLRB referenced in this Article.

30. The incidents are discussed in the following order: first, advice memoranda (in reverse chronological order of when they were issued); second, ALJ decisions (in reverse chronological order of when they were issued); and, last, the one Board decision. Four situations solely involving employer social media policies will be discussed in Part III.B. infra.

31. Advice Memorandum from the NLRB Office of the Gen. Counsel to Director J. Michael Lightner, Regional Director of Region 22, MONOC, No. 22-CA-29008, et al., 2010 WL 4685855, at *2 (May 5, 2010) [hereinafter MONOC Adv. Mem.] (redacting content of actual postings in compliance Freedom of Information Act exemptions 6 and 7(c)), available at http://mynlrb.nlrb.gov/link/document.aspx/09031d45803f7e3b.

32. MONOC Adv. Mem., supra note 31 , at $* 2$.

33. MONOC Adv. Mem., supra note 31 , at*3.

34. NLRB Charge Against Employer, No. 22-CA-29008 (Nov. 16, 2009) (copy on file with author).

35. MONOC Adv. Mem., supra note 31, at *5 (noting "[w] hile other postings on [one employee's] Facebook page clearly involved protected communications regarding terms and conditions of employment and ongoing labor disputes, the specific comments cited by the Employer as the basis of the employees' suspensions did not involve Section 7 concerns and were in no way related to the postings that did"). 
surveillance of their Facebook postings. ${ }^{36}$ In general, surveillance by an employer can restrain employees from engaging in protected concerted activities. ${ }^{37}$ However, "no impression of surveillance is created where the employer explains that it obtained the information from other employees, particularly in the absence of evidence that the employer solicited the information." ${ }^{n 8}$ Here, the managers obtained the Facebook postings from another employee. ${ }^{39}$

\section{B. Dawnmarie Souza Revisited}

As discussed above, Dawnmarie Souza was fired by AMR, in part because she posted disparaging remarks about her supervisor on Facebook. ${ }^{40}$ Part of Souza's dispute with her employer was that she was denied union representation when she was ordered to write an incident report. ${ }^{41}$ The NLRB's Office of the General Counsel concluded that "the written incident report constitute[d] an investigatory interview and that Souza had a right to Union representation when completing the report. Thus, the Employer violated Section 8(a)(1) of the Act by denying Souza a Union representative and threatening to discipline her for invoking her [right to representation]." ${ }^{\text {2 }}$ The General Counsel's office further concluded that Souza was engaged in protected concerted activity when she later discussed with her coworkers, via Facebook, her run-in with her supervisor. $^{43}$

One issue raised in considering Souza's charge was whether she lost NLRA protection by referring to her supervisor as a "17," a "dick," and a "scumbag" in her Facebook post. ${ }^{44}$ The NLRA "protects statements made during the course of protected conduct unless they are so egregious as to

36. NLRB Charge Against Employer, No. 22-CA-29008, supra note 34.

37. MONOC Adv. Mem., supra note 31, at *5 ("Employer surveillance or creation of an impression of surveillance constitutes unlawful interference with Section 7 rights because employees should feel free to participate in union activity 'without the fear that members of management are peering over their shoulders."') (citing Flexsteel Indus., Inc., 311 N.L.R.B. 257, 257 (1993)).

38. MONOC Adv. Mem., supra note 31 , at *6.

39. See MONOC Adv. Mem., supra note 31, at *6 (noting the supervisor had informed the holder of the Facebook profile that the posts were obtained by a "concerned" employee; noting also that the holder of the Facebook profile had restricted access to her posts to her "friends," and therefore "would not reasonably conclude that the Employer was directly monitoring her Facebook page"). See infra Part III.C. for a further discussion of employer surveillance.

40. See supra notes $23-25$ and accompanying text.

41. AMR Adv. Mem., supra note 23, at 3.

42. AMR Adv. Mem., supra note 23, at 6 .

43. AMR Adv. Mem., supra note 23, at 9 (describing Souza's protected concerted activity as "discussing supervisory actions with coworkers in her Facebook post").

44. AMR Adv. Mem., supra note 23, at 9; see also supra text accompanying note 23. 
remove the employee's conduct from the protection of the Act." 45 Four factors are considered when determining whether an employee who is engaged in protected concerted activity has by "opprobrious" conduct lost the protection of the Act: "(1) the place of the discussion; (2) the subject matter of the discussion; (3) the nature of the employee's outburst; and (4) whether the outburst was, in any way, provoked by an employer's unfair labor practice." ${ }^{46}$ The General Counsel's office concluded Souza's conduct was not so opprobrious as to lose the protection of the Act: first, the Facebook postings did not interrupt the work of any employee because they occurred outside the workplace and during the nonworking time of both Souza and her coworkers; second, the comments were made during an online employee discussion of supervisory action, which is protected activity; third, Souza's name-calling was not accompanied by any verbal or physical threats; and fourth, Souza's Facebook postings were provoked by her supervisor's unlawful refusal to provide her with a union representative for the completion of the incident report and by his unlawful threat to discipline her. ${ }^{47}$

The NLRB's Office of the General Counsel also determined that AMR's Internet and Blogging Policy, which prohibited employees from "making disparaging ... comments when discussing the Company or the employee's superiors, co-workers, and/or competitors," was unlawful because it contained no limiting language to inform employees that it did not apply to section 7 activity. ${ }^{48}$ The NLRB settled this matter with AMR, in which AMR agreed to post a notice to its employees that it was revising its Internet and Blogging Policy, acknowledging that it improperly restricted its employees' "right to engage in union activities or to discuss [their] wages, hours and working conditions with [their] fellow employees and others while not at work." ${ }^{, 49}$

\section{Tweeting About Union Negotiations}

Contemporaneous with union negotiations over bonuses and other benefits, Thomson Reuters ("Reuters") launched a "Destination Reuters"

45. AMR Adv. Mem., supra note 23, at 9 (citing Atlantic Steel Co., 245 N.L.R.B. 814, $816(1979))$.

46. AMR Adv. Mem., supra note 23, at 9 (citing Atlantic Steel Co., 245 N.L.R.B. at $816)$.

47. AMR Adv. Mem., supra note 23, at 9-10.

48. AMR Adv. Mem., supra note 23, at 13 (internal quotation marks omitted). See infra Part III.B., for a further discussion of the lawfulness of employer social media policies.

49. NLRB Settlement Agreement, No. 34-CA-12576 (Feb. 7, 2011), available at http://www.minnesotaemploymentlawreport.com/NLRB\%20Facebook\%20Settlement.pdf. Interestingly, the fate of Souza-i.e., whether she was to be reinstated and/or to receive back pay-is not mentioned in the settlement agreement. 
Twitter feed which employees were invited to follow and to "join the conversation as we Tweet on major media play on Reuters and the competition, journalism awards and tips to help you manage your career better at Reuters. ${ }^{, 50}$ At the same time, Reuters also issued Social Media \& Online Communication Guidelines ("Guidelines") and a Handbook of Journalism ("Handbook") "to regulate employees' online participation, including in blogs and social sites like Facebook and Twitter." A1 A Reuters reporter replied to the "Destination Reuters" Twitter feed announcement by sending a tweet stating that "one way to make this place the best place to work is to deal honestly with Guild members." ${ }^{.52}$ The next day, the journalist's bureau chief called to "remind" the reporter that the Company's Twitter policy prohibited tweeting anything that "would damage the reputation of Thomson Reuters" and that her tweet implied that the Reuters was not dealing honestly with the union. ${ }^{53}$

The NLRB's Office of the General Counsel concluded that maintenance of the Guidelines and portions of the Handbook, as well as the application of the Twitter policy to the journalist's tweet exhorting Reuters to "deal honestly with Guild members" violated section $8(a)(1) .{ }^{54}$ While Reuters's social media policy did not explicitly prohibit section 7 activity, the General Counsel's office considered the Guidelines and portions of the Handbook to be unlawful because they would reasonably be construed to apply to section 7 activity that may be critical of Reuters, but is nonetheless protected. $^{55}$ For example, the Guidelines and the Handbook prohibited communications that "attack or insult[,]" or embarrass or disparage, or "damage the reputation" of Reuters, or are "embarrassing to others." ${ }^{.56}$ The General Counsel's office considered these prohibitions as broad terms that would commonly apply to protected criticism of an employer's labor policies or treatment of employees. ${ }^{57}$ It concluded:

Neither the Handbook nor the Guidelines define these broad terms or limit them in any way that would exclude Section 7

50. Advice Memorandum from the NLRB Office of the Gen. Counsel to Karen Fernbach, Acting Regional Director of Region 2, Thomson Reuters, No. 02-CA-39682, 2011 WL 6960026, at *5 (Apr. 5, 2011) [hereinafter Thomson Reuters Adv. Mem.], available at http://mynlrb.nlrb.gov/link/document.aspx/09031d458079355f (internal quotation marks omitted).

51. Thomson Reuters Adv. Mem., supra note 50, at *4.

52. Thomson Reuters Adv. Mem., supra note 50 , at $* 5$ (internal quotation marks omitted).

53. Thomson Reuters Adv. Mem., supra note 50, at $* 5$ (internal quotation marks omitted).

54. Thomson Reuters Adv. Mem., supra note 50, at *14 (internal quotation marks omitted).

55. Thomson Reuters Adv. Mem., supra note 50, at *15.

56. Thomson Reuters Adv. Mem., supra note 50, at *15.

57. Thomson Reuters Adv. Mem., supra note 50, at *15. 
activity. On the contrary, the Employer has actually applied the broad language in its social media policies to restrict Section 7 activity, invoking its policy to reprimand an employee for the protected exhortation to "deal honestly" with the Union. ${ }^{58}$

\section{Tweeting that TV People Are Stupid}

Brian Pedersen was a reporter with the Arizona Daily Star. In response to an initiative by the Daily Star to encourage "reporters to use social media to get news stories out to people who might not read the newspaper and to drive readers to the Daily Star's website[,]"59 Pedersen attended a "webinar" about how to use Twitter and opened a Twitter account. ${ }^{60}$ About a year later, Pederson posted a tweet stating: "The Arizona Daily Star's copy editors are the most witty and creative people in the world. Or at least they think they are."61 About two weeks later, Pedersen was called into a meeting with his supervisors, who expressed concern about his tweet and informed him he was "prohibited from airing his grievances or commenting about the Daily Star in any public forum."62 Approximately eight months later, over a period of four weeks, Pedersen posted a series of tweets trivializing the Tucson-area homicide rate, and calling "TV people" stupid in response to a misspelled word in a television station's tweet. ${ }^{63}$ Pedersen was subsequently fired because he disregarded guidance "to refrain from using derogatory comments in any social media forums that may damage the goodwill of the company," and because of his "inappropriate Twitter posting.",64

The NLRB's Office of the General Counsel concluded Pedersen "was terminated for writing inappropriate and offensive Twitter postings that did not involve protected concerted activity." 65 In particular, Pedersen's "conduct was not protected and concerted: it did not relate to the terms and conditions of his employment or seek to involve other employees in issues

58. Thomson Reuters Adv. Mem., supra note 50, at *15.

59. Advice Memorandum from the NLRB Office of the Gen. Counsel to Cornele A. Overstreet, Regional Director of Region 28, Lee Enterprises, Inc., d/b/a/ Arizona Daily Star, No. 28-CA-23267, 2011 WL 1825089, at *1 (Apr. 21, 2011) [hereinafter Daily Star Adv. Mem.], available at http://mynlrb.nlrb.gov/link/document.aspx/09031d4580495256; see also NLRB Charge Against Employer, No. 28-CA-23267 (Nov. 24, 2010) (copy on file with author).

60. Daily Star Adv. Mem., supra note 59, at*1.

61. Daily Star Adv. Mem., supra note 59, at *2 (internal quotation marks omitted) (noting that the tweet was in response to certain sports headlines).

62. Daily Star Adv. Mem., supra note 59, at *2 (internal quotation marks omitted).

63. Daily Star Adv. Mem., supra note 59, at *2-3.

64. Daily Star Adv. Mem., supra note 59, at *4.

65. Daily Star Adv. Mem., supra note 59, at*4. 
related to employment." ${ }^{\text {"6 }}$ Although supervisors admonished Pedersen "to stop airing his grievances or commenting about the Employer in any public forum[,]" and "to refrain from using derogatory comments in any social media forums that may damage the goodwill of the company"-which could be interpreted as overly broad rules that prohibit protected concerted activities - here, "the statements were made solely to the Charging Party [Pedersen] in the context of discipline, and in response to specific inappropriate conduct, and were not communicated to any other employees or proclaimed as new "“rules.",67

\section{E. When a Supervisor Complains About a Coworker}

Kathleen Reichle and her fellow nurses were upset that another nurse frequently missed her shifts, and although they had complained to their manager, no action had been taken to rectify the matter. ${ }^{68}$ After the nurse called in sick again, Reichle posted a comment on her Facebook page complaining about the nurse, ending with: "Anymore details, contact me." ${ }^{69}$ Reichle was subsequently fired because she had "talked badly about the hospital" in violation of the hospital's social media policy. ${ }^{70}$

The Board considers an employer to have violated section 8(a)(1) of the NLRA if it maintains a work rule that would "reasonably tend to chill employees in the exercise of their Section 7 rights." 71 While a rule that explicitly restricts section 7 activities is unlawful, so too can a rule that implicitly restricts section 7 activities if one of three conditions is met: "(1) employees would reasonably construe the language to prohibit Section 7

66. Daily Star Adv. Mem., supra note 59, at *5.

67. Daily Star Adv. Mem., supra note 59, at *5-6.

68. Advice Memorandum from the NLRB Office of the Gen. Counsel to Rochelle Kentov, Regional Director of Region 12, Flagler Hospital, No. 12-CA-27031, 2011 WL 5115074, at *1 (May 10, 2011) [hereinafter Flagler Hosp. Adv. Mem.], available at http://mynlrb.nlrb.gov/link/document.aspx/09031d45806bab9c; see also NLRB Charge Against Employer, No. 12-CA-26947 (Nov. 16, 2010) (copy on file with author).

69. Flagler Hosp. Adv. Mem., supra note 68, at *1 (internal quotation marks omitted).

70. Flagler Hosp. Adv. Mem., supra note 68 , at $* 2$ (internal quotation marks omitted). Reichle withdrew her original charge that she was fired in violation of the NLRA because she was classified as a supervisor. Flagler Hosp. Adv. Mem., supra note 68, at*2. Section 7 applies to employees. 29 U.S.C. $§ 157$ ("Employees shall have the right ... to engage in ... concerted activities for the purpose of ... mutual aid or protection") (emphasis added). And the NLRA's definition of employee excludes supervisors. 29 U.S.C. § 152(3). The General Counsel's office concluded, however, that had she not been a supervisor, Reichle's postings would have clearly been protected concerted activity. Reichle subsequently filed a new charge alleging that certain provisions of the hospital's social media policy were unlawful. Flagler Hosp. Adv. Mem., supra note 68, at *2.

71. Flagler Hosp. Adv. Mem., supra note 68, at *2 (citing Lafayette Park Hotel, 326 N.L.R.B. 824, 825 (1998), enforced sub nom. Lafayette Park Hotel v. NLRB, 203 F.3d 52 (D.C. Cir. 1999) (internal quotation marks omitted)). 
activity; (2) the rule was promulgated in response to union activity; or (3) the rule has been applied to restrict the exercise of Section 7 rights." ${ }^{.72}$

The NLRB's Office of the General Counsel concluded that three of the hospital's policies were unlawful. The hospital prohibited employees from using any social media that "may in any way violate, compromise, or disregard... the rights and reasonable expectations as to privacy or confidentiality of any person or entity." 73 Since the hospital did not provide a definition or guidance as to what it considers to be private or confidential, the General Counsel's office concluded the rule was overly broad, in that it could reasonably be interpreted as prohibiting protected employee discussion of wages and other terms and conditions of employment. $^{74}$

A second hospital rule prohibited the use of social media to post "[a]ny communication or post which constitutes embarrassment, harassment or defamation of the Hospital" or of "any employee, officer, board member, representative or staff member." 75 The General Counsel's office noted that this particular rule was the one relied upon by the hospital to fire Reichle because of her Facebook postings, which would have been protected if she had been a statutory employee. ${ }^{76}$ As such, the hospital's "interpretation and application of that [rule] to cover the Charging Party's expression of frustration over a colleague's conduct that frequently resulted in heavier demands on the remaining staff could reasonably lead employees to conclude that protected complaints about their working conditions are prohibited." 77

The final rule considered by the NLRB's Office of the General Counsel prohibited "statements which lack ... truthfulness or which might cause damage to or does damage the reputation or goodwill of the Hospital ...."78 The General Counsel's office concluded this rule was ambiguous because its terms could be applied to protected criticism of the hospital's labor policies or treatment of employees. ${ }^{79}$ In addition, this last rule contained a savings clause, stating its prohibitions were limited to conduct "or form of expression which, under the law, is or may be

72. Flagler Hosp. Adv. Mem., supra note 68 , at *2 (citing Lutheran Heritage VillageLivonia, 343 N.L.R.B. 646, 647 (2004)).

73. Flagler Hosp. Adv. Mem., supra note 68 , at *2 (internal quotation marks omitted).

74. Flagler Hosp. Adv. Mem., supra note 68 , at $* 2$

75. Flagler Hosp. Adv. Mem., supra note 68 , at $* 3$ (alteration in original) (internal quotation marks omitted).

76. Flagler Hosp. Adv. Mem., supra note 68 , at *3; see supra note 70 (discussing Reichle's lack of standing under section 7 because she was a supervisor and not an "employee").

77. Flagler Hosp. Adv. Mem., supra note 68, at*3.

78. Flagler Hosp. Adv. Mem., supra note 68 , at *3 (internal quotation marks omitted).

79. Flagler Hosp. Adv. Mem., supra note 68, at*3. 
impermissible." ${ }^{\prime 80}$ The Board has held that an employer may not prohibit employee activity protected by the NLRA and then seek to escape the consequences of the prohibition by a general reference to rights protected by law. ${ }^{81}$ More specifically, the Board has explained that "these general provisions, known as savings clauses or disclaimers, that employers tack onto the end of a rule that otherwise prohibits, coerces, or restrains employees in the exercise of their Section 7 rights, do not make an otherwise unlawful rule lawful." ${ }^{, 82}$

\section{F. Complaining About Work on a U.S. Senator's Facebook Wall}

In January 2011, Lori Russell-Head, a dispatcher for a company that provides emergency and nonemergency medical transportation and fire protection services in Indiana, posted a message on Senator Dick Lugar's (R-IN) Facebook wall, complaining that she and her husband were underpaid employees of a private contractor providing public services. ${ }^{83}$ Russell-Head claimed that "she wanted to make Senator Lugar aware that she disagreed with how emergency medical services were handled in Indiana and that her kind of company was not helping the current situation." 84 Russell-Head was subsequently fired "for publicly posting disparaging remarks about the Employer and confidential information about its response to a service call[,]" and because her Facebook comments violated the Employer's Code of Ethics and Business Conduct policy. ${ }^{85}$

The NLRB's Office of the General Counsel determined RussellHead's firing was not unlawful because she did not engage in concerted activity. She did not discuss her Facebook posting with any other employee; there had been no employee meetings or any attempt to initiate group action; she was not trying to take employee complaints to management; and, admittedly, did not expect Senator Lugar to take any action that would affect her employment situation. ${ }^{86}$ Rather, she was

80. Flagler Hosp. Adv. Mem., supra note 68, at*3. (internal quotation marks omitted).

81. Flagler Hosp. Adv. Mem., supra note 68 , at *3; Tower Indus. Inc., d/b/a Allied Mech., 349 N.L.R.B. 1077, 1084 (2007) (“An employer may not specifically prohibit employee activity protected by the Act and then seek to escape the consequences of the specific prohibition by a general reference to rights protected by law.").

82. Flagler Hosp. Adv. Mem., supra note 68, at *3.

83. Advice Memorandum from the NLRB Office of the Gen. Counsel to Rik Lineback, Regional Director of Region 25, Rural Metro, No. 25-CA-31802, 2011 WL 2960970, at *1 (June 29, 2011) [hereinafter Rural/Metro Adv. Mem.], available at http://mynlrb.nlrb.gov/link/document.aspx/09031d458055fad2; see also NLRB Charge Against Employer, No. 25-CA-31802 (Mar. 14, 2011) (copy on file with author).

84. Rural/Metro Adv. Mem., supra note 83, at*1.

85. Rural/Metro Adv. Mem., supra note 83 , at $* 2$.

86. Rural/Metro Adv. Mem., supra note 83 , at $* 2$. 
"merely trying to make a public official aware of the state of emergency medical services in Indiana." 87

\section{G. Discussing Tip Sharing with a Step-Sister}

In February 2011, Bradley Denney, a bartender at JT's Porch Saloon \& Eatery, engaged in a Facebook "conversation" with his step-sister. ${ }^{88}$ In response to his step-sister's inquiry as to how work was going, Denney responded that he had not received a raise in five years and that he was doing the waitresses' work without tips; he also called the employer's customers "rednecks" and stated that he "hoped they choked on glass as they drove home drunk." ${ }^{~} 9$ JT's maintains an unwritten policy, communicated to bartenders when they are hired, that waitresses do not share their tips with the bartenders even though the bartenders help the waitresses serve food. ${ }^{90}$ Although Denney discussed the tip sharing policy with another bartender and she agreed the policy "sucked," they never took their complaint to management; nor did any other coworkers participate in the Facebook conversation between Denney and his step-sister. ${ }^{91}$ Two months later, Denney was fired "for his Facebook posting about the Employer's customers." 92

The NLRB's Office of the General Counsel concluded Denney was not unlawfully fired because he did not engage in concerted activity:

Here, there is no evidence of concerted activity. Although the Charging Party's posting addressed his terms and conditions of employment, he did not discuss his Facebook posting with any of his fellow employees either before or after he wrote it, and none of his coworkers responded to the posting. There had been no employee meetings or any attempt to initiate group action with regard to the tipping policy or the awarding of raises. There also was no effort to take the bartenders' complaints about these matters to management. In this instance, the Charging Party was merely responding to a question from his step-sister about how

87. Rural/Metro Adv. Mem., supra note 83 , at $* 2$.

88. Advice Memorandum from the NLRB Office of the Gen. Counsel to Gail R. Moran, Acting Regional Director of Region 13, JT's Porch Saloon \& Eatery, Ltd., No. 13CA-46689, 2011 WL 2960964, at *1 (July 7, 2011) [hereinafter JT's Porch Adv. Mem.], available at http://mynlrb.nlrb.gov/link/document.aspx/09031d458055b9c6; see also N.L.R.B. Charge Against Employer, No. 13-CA-46689 (Apr. 5, 2011) (copy on file with author).

89. JT's Porch Adv. Mem., supra note 88, at*1.

90. JT's Porch Adv. Mem., supra note 88, at*1.

91. JT's Porch Adv. Mem., supra note 88, at*1.

92. JT's Porch Adv. Mem., supra note 88 , at *1. Ironically, the day before he was formally fired, the owner of JT's Porch informed Denney that "his services were no longer required" through a Facebook posting. JT's Porch Adv. Mem., supra note 88, at*1. 
his evening at work went. And this internet "conversation" did not grow out his prior conversation with a fellow bartender months earlier about the tipping policy. ${ }^{93}$

\section{H. Expressing Frustration with Wal-Mart}

In October 2010, after an interaction with a new Assistant Manager, Brian Morris, a Wal-Mart employee, posted on his Facebook page, "Wuck Falmart! I swear if this tyranny doesn't end in this store they are about to get a wakeup call because lots are about to quit!"94 Two coworkers posted short comments generally agreeing with Morris's sentiments, and Morris posted another comment criticizing the Assistant Manager. ${ }^{95}$ Morris was subsequently disciplined for his Facebook postings. ${ }^{96}$ The NLRB's Office of the General Counsel concluded that Morris's charge against Wal-Mart should be dismissed because he did not engage in concerted activity; his postings were merely "an expression of an individual gripe." 97

\section{Talking About Mentally Disabled Clients}

In January 2011, an employee of Martin House, a nonprofit residential facility for homeless people, engaged in a "conversation" on her Facebook wall in which she stated it was "spooky" being all alone "in a mental institution." 98 No coworkers were involved in the conversation; however, a former client was Facebook friends with the employee and saw the posts and reported them to the employer. ${ }^{99}$ The employee was subsequently fired as a result of the Facebook posts. ${ }^{100}$ The NLRB's Office of the General Counsel concluded the employee's firing was not unlawful because she had not engaged in concerted activity. ${ }^{101}$ Not only were no coworkers involved in the Facebook conversation, it did not even mention any terms or

93. JT's Porch Adv. Mem., supra note 88 , at $* 2$.

94. Advice Memorandum from the NLRB Office of the Gen. Counsel to Daniel L. Hubbel, Regional Director of Region 17, Wal-Mart, No. 17-CA-25030, 2011 WL 3223852, at *1 (July 19, 2011) [hereinafter Wal-Mart Adv. Mem.], available at http://mynlrb.nlrb.gov/link/document.aspx/09031d458056e73d; see also N.L.R.B. Charge Against Employer, No. 17-CA-25030 (Dec. 9, 2010) (copy on file with author).

95. Wal-Mart Adv. Mem., supra note 94, at*1.

96. Wal-Mart Adv. Mem., supra note 94 , at*1.

97. Wal-Mart Adv. Mem., supra note 94, at*2.

98. Advice Memorandum from the NLRB Office of the Gen. Counsel to Jonathan B. Kresiberg, Regional Director of Region 34, Martin House, No. 34-CA-12950, 2011 WL 3223853, at *1 (July 19, 2011) [hereinafter Martin House Adv. Mem.], available at http://mynlrb.nlrb.gov/link/document.aspx/09031d458056e73e.

99. Martin House Adv. Mem., see supra note 98, at*1.

100. Martin House Adv. Mem., see supra note 98, at*1.

101. Martin House Adv. Mem., see supra note 98, at*2. 
conditions of employment. ${ }^{102}$ The employee "was merely communicating with her personal friends about what was happening on her shift.", 103

\section{J. Complaining About a Dispatcher}

In December 2010, Gregory Crawford, a truck driver employed by Buel, Inc., was stuck outside of Laramie, Wyoming, due to snow and was unable to reach a dispatcher. ${ }^{104}$ He posted a complaint about his situation on his Facebook page. ${ }^{105}$ Crawford was subsequently demoted, after which he quit, claiming he was constructively discharged as a result of his Facebook posting. ${ }^{106}$ The NLRB's Office of the General Counsel concluded that Crawford had not engaged in concerted activity. ${ }^{107}$ Rather than collectively communicating with fellow employees regarding work conditions, the General Counsel's office concluded Crawford "was simply expressing his own frustration and boredom while stranded by the weather, by griping about his inability to reach the on-call dispatcher."108

Crawford also accused his employer of surveillance of his Facebook account. ${ }^{109}$ Here, Crawford had "friended" his supervisor on Facebook, essentially inviting her to view his Facebook page. ${ }^{110}$ Further, there was no evidence that the supervisor "was acting at the Employer's direction or was on Facebook for the sole purpose of monitoring employee postings.",

\section{K. Accusing a Supervisor of Having an Affair}

In 2010, an employee of Sagepoint Financial, Inc., sent a number of email messages and wrote several Facebook posts complaining about his situation at work, namely, that his supervisor had been chosen over him for a promotion, she had hired two incompetent employees, and suggesting that she was having an affair with one of them. ${ }^{12}$ In Facebook posts, he

102. Martin House Adv. Mem., see supra note 98 , at *2.

103. Martin House Adv. Mem., see supra note 98, at *2.

104. Advice Memorandum from the NLRB Office of the Gen. Counsel to Jane North, Acting Regional Director of Region 11, Buel, Inc., No. 11-CA-22936, 2011 WL 3793671, at *1 (July 28, 2011) [hereinafter Buel Adv. Mem.], available at http://mynlrb.nlrb.gov/link/document.aspx/09031d45805fa $7 \mathrm{fc}$; see also N.L.R.B. Amend. Charge Against Employer, No. 11-CA-22936 (Mar. 28, 2011) (copy on file with author).

105. Buel Adv. Mem., supra note 104, at*1.

106. Buel Adv. Mem., supra note 104, at *2.

107. Buel Adv. Mem., supra note 104 , at $* 2$.

108. Buel Adv. Mem., supra note 104, at *2.

109. N.L.R.B. Amend. Charge Against Employer, No. 11-CA-22936, supra note 104.

110. Buel Adv. Mem., supra note 104, at*3.

111. Buel Adv. Mem., supra note 104, at*3.

112. See Sagepoint Fin. Adv. Mem., supra note 12, at*1. 
stated that he hated his supervisor and called her a bitch. ${ }^{113}$ Although the employee was initially Facebook friends with several coworkers and supervisors, he subsequently "unfriended" most of his coworkers and continued to vent online about his supervisor. ${ }^{114}$ The employee was initially reprimanded and admonished to "conduct [himself] in a professional manner; do not disrespect other employees or your management team or make negative comments." 115 The employer ultimately terminated the employee "for continual behavior problems and his inability to interact with his coworkers and manager, referencing his emails and Facebook postings." 116

In concluding the employer did not unlawfully fire the employee because he was not engaged in concerted activity, ${ }^{117}$ the NLRB's Office of the General Counsel stated:

Here, the Charging Party's repeated Facebook complaints about his supervisor and what he perceived to be her preferential treatment of two coworkers were made solely on his own behalf and were not designed to advance any cause other than his own. Moreover, he did not evidence any intention of instigating group action or bringing any group concern to management. When coworkers participated in these Facebook "conversations," they did so only to express amusement or sympathy but not because they shared a common concern about the effects of the supervisor's conduct upon their terms and conditions of employment. ${ }^{118}$

\section{Calling a Fellow Bartender a Cheater}

In late 2010, Janelle Morehart began posting her concerns on Facebook about a new fellow bartender, a friend of the new general manager of Rock Wood Fired Pizza \& Spirits, claiming he was a "cheater" and "screwing" customers because he was using mixes instead of premium liquors, and stating: "Dishonest employees along with management that turns their head, will be the death of any business."

113. See Sagepoint Fin. Adv. Mem., supra note 12, at*1.

114. See Sagepoint Fin. Adv. Mem., supra note 12, at*1-2.

115. See Sagepoint Fin. Adv. Mem., supra note 12, at *1 (internal quotation marks omitted).

116. See Sagepoint Fin. Adv. Mem., supra note 12, at *2 (internal quotation marks omitted).

117. See Sagepoint Fin. Adv. Mem., supra note 12, at *2.

118. See Sagepoint Fin. Adv. Mem., supra note 12, at*3.

119. Rock Wood Adv. Mem., supra note 16, at*1-2 (internal quotation marks omitted); see also N.L.R.B. Charge Against Employer, No. 19-CA-32981 (Feb. 28, 2011) (copy on file with author). 
employees were concerned that customers would see the posts. ${ }^{120}$ Morehart was subsequently fired for " $[\mathrm{u}] \mathrm{se}$ of unprofessional communication on her $[F]$ acebook to fellow employees viewed by employees." 121

The NLRB's Office of the General Counsel concluded Morehart's activity was not protected under the NRLA. ${ }^{122}$ However, the General Counsel's office did agree that the employer's "Team Member Conduct \& Work Rules" were unlawfully broad because the prohibitions on "disrespectful conduct" and "inappropriate conversations" would reasonably be construed by employees to preclude section 7 activity. ${ }^{123}$ However, discipline imposed under an unlawfully overly broad rule violates the NLRA only when the affected employee has been engaging in protected concerted activity. ${ }^{124}$ As noted by the Office of the General Counsel:

Here, the Charging Party's Facebook posts regarding her fellow bartender's job performance had only a very attenuated connection with terms and conditions of employment. She made the posts because she was upset that he was passing off lowgrade drinks as premium liquor and management was condoning the action .... Although she later stated that she was concerned that the bartender's conduct would cause customers to stop buying drinks or lower their tips if they found out, she did not state this concern in her posts. And this assertion is belied by the fact that she was communicating with customers about the bartenders' [sic] conduct, which if anything would cause the impact on business she now asserts she was trying to prevent. ${ }^{125}$

\section{Posting That You Are a Hair Away from Setting It Off}

In January 2011, a Frito-Lay employee was upset that his supervisor would subtract "attendance points" if the employee left early because he was not feeling well, posting his frustration on Facebook: "I think they trying to give me a reason to be fired because I'm about a hair away from setting it off in that BITCH.hahahaha." 126 The HR Manager considered the

120. A coworker responded to the post indicating Morehart should be careful about posting on Facebook. Rock Wood Adv. Mem., supra note 16, at *2 (citing a coworker who posted: "[I] agree . . . careful what u post, feel me?").

121. Rock Wood Adv. Mem., supra note 16, at *2 (internal quotation marks omitted).

122. Rock Wood Adv. Mem., supra note 16, at *2.

123. Rock Wood Adv. Mem., supra note 16, at *2 (internal quotation marks omitted).

124. Rock Wood Adv. Mem., supra note 16, at*2.

125. Rock Wood Adv. Mem., supra note 16, at *3.

126. Advice Memorandum from the NLRB Office of the Gen. Counsel to Richard L. Ahearn, Regional Director of Region 19, Frito-Lay, Inc., No. 36-CA-10882, 2011 WL 4526828, at *1 (Sept. 19, 2011) [hereinafter Frito-Lay Adv. Mem.], available at http://mynlrb.nlrb.gov/link/document.aspx/09031d4580681026. 
employee's post a threat and suspended the employee pending an investigation, and subsequently fired the employee because his "Facebook comments were inappropriate, threatening and violent." ${ }^{127}$

The NLRB's Office of the General Counsel concluded there was no evidence of concerted activity. ${ }^{128}$ "Although the [employee's] postings addressed his terms and conditions of employment, he did not seek to initiate or induce coworkers to engage in group action, and none of his coworkers responded to the postings with similar concerns."

\section{N. Using an Obscenity as Your Job Title on LinkedIn}

In early 2010, an employee of Schulte, Roth \& Zabel was invited by a fellow employee to join the LinkedIn online networking site. ${ }^{130}$ The invited employee accepted the invitation, which, because LinkedIn is a professional- and business-related website, included the entry of job-related information, such as the name of employer and job title. As a joke, thinking only his supervisor would see it, the invited employee entered his job title as "fucktard." 131 A few months later, as the employer began investigating setting up its own LinkedIn site, it began viewing its own employees' profiles on LinkedIn and discovered the employee's joke job title; thereafter discharging him for violating the employer's Electronic Communication Policy by disparaging the company. ${ }^{132}$ The NLRB's Office of the General Counsel fundamentally concluded that the employee's LinkedIn "joke" was clearly not protected concerted activity. ${ }^{133}$

The employee had claimed the LinkedIn job description was merely a pretext for dismissing him due to his conversations with other employees about the employer's overtime compensation, noting the LinkedIn "joke" was online for over a year before he was fired, though he had begun the overtime conversations only two months earlier. ${ }^{134}$ The NLRB's Office of the General Counsel noted that "timing alone does not establish a prima facie case." 135 In particular, there was no evidence the employer was even aware of the employee's overtime discussions. ${ }^{136}$

127. Frito-Lay Adv. Mem., supra note 126 at*2.

128. Frito-Lay Adv. Mem., supra note 126 at *2.

129. Frito-Lay Adv. Mem., supra note 126 at *2.

130. Advice Memorandum from the NLRB Office of the Gen. Counsel to Elbert F. Tellem, Acting Regional Director for Region 2, Schulte, Roth \& Zabel, No. 02-CA-60476, 2011 WL 5122642, at *1 (Oct. 13, 2011) [hereinafter Schulte, Roth \& Zabel Adv. Mem.], available at http://mynlrb.nlrb.gov/link/document.aspx/09031d45806bab9f.

131. Schulte, Roth \& Zabel Adv. Mem., supra note 130, at*1.

132. Schulte, Roth \& Zabel Adv. Mem., supra note 130, at*1.

133. Schulte, Roth \& Zabel Adv. Mem., supra note 130, at*1.

134. Schulte, Roth \& Zabel Adv. Mem., supra note 130, at*1.

135. Schulte, Roth \& Zabel Adv. Mem., supra note 130, at*1 (citing Wright Line, 251

N.L.R.B. 1083, 1089 (1980) (requiring that the General Counsel make a prima facie 


\section{O. Complaining About a Customer on Facebook}

During a lunch break in April 2011, a service representative of a credit union posted a comment on his Facebook page describing an interaction with a customer that resulted in the customer lodging a complaint against the representative (based on the interaction, not the Facebook posting). ${ }^{137}$ The employee's initial posting was followed by an online "conversation" with two friends generally denigrating the customer and the employee's supervisor. ${ }^{138}$ A few days later, the employee again vented about work via Facebook, with a customer "friend" joining the "conversation." 139 The employee was subsequently fired for making derogatory statements about a customer. $^{140}$ In concluding the employee was not engaged in protected concerted activity, ${ }^{141}$ the NLRB's Office of the General Counsel stated:

Here, the Charging Party's ... Facebook post, for which he was discharged, was merely an expression of an individual gripe about a customer. The Charging Party admitted that he posted this comment because he was frustrated and that he was not trying to get other employees to take any action. Indeed, the post contains no language suggesting that he sought to initiate or induce coworkers to engage in group action, and the post did not grow out of a prior discussion about terms and conditions of employment with his coworkers or even reference terms and conditions of employment. As he put it, he was merely "venting.","142

\section{P. Posting on Facebook That a Coworker's "Sucking His Teeth" is Driving You Nuts}

In January 2011, a respiratory therapist was traveling in an ambulance with coworkers to pick up a patient. One of the coworkers kept sucking his

showing sufficient to support the inference that protected conduct was a motivating factor in the employer's decision; and once this is established, the burden will shift to the employer to demonstrate that the same action would have taken place even in the absence of the protected conduct)).

136. Schulte, Roth \& Zabel Adv. Mem., supra note 130, at*1. See infra notes $352-54$ and accompanying text for a discussion of the lawfulness of the employer's Electronic Communication Policy.

137. Advice Memorandum from the NLRB Office of the Gen. Counsel to Wanda Pate Jones, Regional Director of Region 27, Public Service Credit Union, No. 27-CA-21923, 2011 WL 5822506, at *1 (Nov. 1, 2011) [hereinafter Public Service Credit Union Adv. Mem.], available at http://mynlrb.nlrb.gov/link/document.aspx/09031d45806fc018.

138. Public Service Credit Union Adv. Mem., supra note 137, at *2.

139. Public Service Credit Union Adv. Mem., supra note 137, at *2.

140. Public Service Credit Union Adv. Mem., supra note 137, at *2.

141. Public Service Credit Union Adv. Mem., supra note 137, at*3.

142. Public Service Credit Union Adv. Mem., supra note 137, at*3. 
teeth during the ride to pick up the patient, irritating the therapist to the point she used her iPhone to post on her Facebook page, "REALLY!!!! Must you suck your teeth every 30 seconds. It is driving me nuts."143 Two of her Facebook nonemployee friends responded with supporting comments and, in reply, the employee wrote: "Actually they are about to get, beat senseless with a ventilator. [sic] It's in the back of an ambulance and I can't get away from them. UGH!!!"144 A coworker saw the Facebook post and reported it to the employer, considering it a threat. ${ }^{145}$ The therapist was suspended for two days "because of her negative and threatening Facebook comments" about her coworker. ${ }^{146}$

In concluding the employee was not engaged in protected concerted activity and therefore the employer did not violate the Act by disciplining her, ${ }^{147}$ the NLRB's Office of the General Counsel stated:

The Charging Party's ... post was not protected because it did not concern terms and conditions of employment. She was merely complaining about the irritating sounds her coworker was making during the transport that evening, and was not even suggesting that the Employer should do anything about it. Therefore, her complaint about the co-worker's noises, and her alleged threat to hit him with a ventilator to stop them, is not Section 7 protected. ${ }^{148}$

\section{Q. Accusing Your Employer of Fraud}

During the early part of 2011, an accountant-employee of TAW, Inc., was working with an outside auditor to complete the employer's annual audit. ${ }^{149}$ During the audit, the employee's supervisor informed her that the supervisor had made a serious accounting error that resulted in a large overstatement of revenue and rather than correct the error, the employer's Chief Operating Officer had decided to allocate it over the rest of the year. ${ }^{150}$ The employee was concerned this tactic contravened generally

143. Advice Memorandum for the NLRB Office of the Gen. Counsel to Wayne Gold, Regional Director of Region 5, Children's National Medical Center, No. 05-CA-36658, 2011 WL 6009620, at*1 (Nov. 14, 2011) [hereinafter Children's Nat'l Med. Ctr. Adv. Mem.], available at http://mynlrb.nlrb.gov/link/document.aspx/09031d45806fc01d.

144. Children's Nat'l Med. Ctr. Adv. Mem., supra note 143, at*1.

145. Children's Nat'l Med. Ctr. Adv. Mem., supra note 143, at*1.

146. Children's Nat'l Med. Ctr. Adv. Mem., supra note 143, at*1.

147. Children's Nat'1 Med. Ctr. Adv. Mem., supra note 143, at*2.

148. Children's Nat'l Med. Ctr. Adv. Mem., supra note 143, at*2.

149. Advice Memorandum from the NLRB Office of the Gen. Counsel to Ronald K. Hooks, Regional Director of Region 26, TAW, Inc., No. 26-CA-63082, 2011 WL 6543304, at $* 1$ (Nov. 22, 2011) [hereinafter TAW Adv. Mem.], available at http://mynlrb.nlrb.gov/link/document.aspx/09031d4580755f55.

150. TAW Adv. Mem., supra note 149 , at $* 1$. 
accepted accounting principles ("GAAP"), particularly because the employee was going to be asked to sign a letter of representation at the conclusion of the audit stating that, to the best of her knowledge, the information was true, accurate, and correct, and that she was not aware of any fraud. ${ }^{151}$ The employee ultimately discussed the situation with the employer's general counsel, who promised to look into the matter. ${ }^{152}$ On April 15, when the audit was complete, the employee confirmed the error had not been corrected and refused to sign the letter of representation. ${ }^{153}$

A meeting was scheduled for April 18 with the employee, her supervisor, the general counsel, and the outside auditor. Prior to the April 18 meeting, the employee posted on her Facebook page, "I wonder if accounting degrees used to be given out based on different criteria since I am fairly certain GAAP standards have always deemed certain things fraud." 154 Although the employer was aware of the employee's Facebook post prior to the April 18 meeting, it was not discussed at the meeting. ${ }^{155}$ However, at the meeting, the auditor assured the employee that the employer was not engaged in fraud and that the audit conformed to generally accepted accounting principles, and the employee signed the letter of representation at the end of the meeting. ${ }^{156}$

A few days later, the employer's general counsel informed the employee that the employer was aware of the employee's Facebook post suggesting the employer was engaged in fraud, and asked the employee to remove the post. ${ }^{157}$ The employee did not believe she should be required to remove the post and did not do so. ${ }^{158}$ A few days later the employee was fired for refusing to remove the post. ${ }^{159}$

The NLRB's Office of the General Counsel concluded the employee was not engaged in conduct protected by section $7 .{ }^{160}$ In particular, the General Counsel's office determined that the employee was informed at the April 18 meeting that the employer was not engaged in fraud; therefore, she was aware her Facebook post was false and her subsequent insistence on retaining the post was not protected activity. ${ }^{161}$

151. TAW Adv. Mem., supra note 149, at*1.

152. TAW Adv. Mem., supra note 149, at*1.

153. TAW Adv. Mem., supra note 149, at*1.

154. TAW Adv. Mem., supra note 149 , at *1.

155. TAW Adv. Mem., supra note 149, at *2.

156. TAW Adv. Mem., supra note 149 , at $* 2$.

157. TAW Adv. Mem., supra note 149 , at $* 2$.

158. TAW Adv. Mem., supra note 149 , at $* 2$.

159. TAW Adv. Mem., supra note 149 , at $* 2$.

160. TAW Adv. Mem., supra note 149, at*2.

161. TAW Adv. Mem., supra note 149, at *2. (citing Valley Hosp. Med. Ctr., 351 N.L.R.B. 1250, 1252 (2007) ("Statements are unprotected if they are maliciously untrue, i.e., if they are made with knowledge of their falsity or with reckless disregard for their truth or falsity.")). 


\section{R. Complaining that Coworkers Are "Narcs"}

At the end of their shifts, bank tellers at Copiah Bank are required to report a list of transactions to the bank's main branch so that it can balance the transactions on an ongoing basis throughout the day. ${ }^{162}$ On one particular day, one of the bank tellers was blamed for a delay in balancing the transactions because she could not send her transactions at the usual time because a customer was still in the bank. ${ }^{163}$ Later that evening, the teller posted on her Facebook page, "[h]ates it when idiot people narc and they have no clue what they are talking about!!" 164 In response to the post, there was a short online "conversation" between the teller and a nonemployee relative. ${ }^{165}$ In addition, a coworker from the main branch asked, via Facebook, whether the teller was talking about the coworker, to which the teller replied, "[n]ot just you but everybody else down there."

The following day, the teller was instructed to remove the Facebook post, which she did. ${ }^{167}$ In addition, the teller apologized, via Facebook, to the coworker in the main branch. ${ }^{168}$ The next day, the teller was informed that the CEO of the bank had ordered the teller's termination because he "didn't like to be called an idiot."169 However, a few days later, the CEO reconsidered and told the teller she could return to her job if she would issue an apology to all bank employees, which she refused to do. ${ }^{170}$

The NLRB's Office of the General Counsel concluded that the teller did not post her comment on her Facebook page in furtherance of concerted activity for mutual aid or protection - the teller admitted that she was not speaking on behalf of any other employees, nor was there evidence that she was looking to engage in group action when she posted her comments on

162. Advice Memorandum from the NLRB Office of the Gen. Counsel to Kathleen McKinney, Regional Director of Region 15, Copiah Bank, No. 15-CA-61204, 2011 WL 6543300, at *1 (Dec. 1, 2011) [hereinafter Copiah Bank Adv. Mem.], available at http://mynlrb.nlrb.gov/link/document.aspx/09031d4580755f54.

163. Copiah Bank Adv. Mem., supra note 162, at*1.

164. Copiah Bank Adv. Mem., supra note 162, at *2. The NLRB recognized the bank teller "was not referring literally to narcotics or a narcotics agent, but was using 'narc' in the colloquial sense of 'tattling' on someone else." Copiah Bank Adv. Mem., supra note 162, at *n1.

165. Copiah Bank Adv. Mem., supra note 162, at*1.

166. Copiah Bank Adv. Mem., supra note 162, at*1. (implying "down there" meant the bank's main branch).

167. Copiah Bank Adv. Mem., supra note 162, at*1.

168. Copiah Bank Adv. Mem., supra note 162, at*1.

169. Copiah Bank Adv. Mem., supra note 162, at *2 (internal quotation marks omitted).

170. Copiah Bank Adv. Mem., supra note 162, at*2. 
Facebook. ${ }^{171}$ As such, the bank did not violate the NLRA by discharging her. ${ }^{172}$

\section{S. Poor Performance Coupled with Facebook Postings}

A director at Intermountain Specialized Abuse Treatment Center, a provider of therapy services to individuals and families who are affected by domestic violence or sexual abuse (as well as offenders), was monitoring one of the therapists for poor performance, particularly conduct during therapy sessions. ${ }^{173}$ At one point during this period, the director announced at a staff meeting that the therapist was to be replaced for certain group therapy sessions. That night, the therapist posted a complaint about work on her Facebook page, to which friends and relatives responded. ${ }^{174}$ The following day, however, in response to the Facebook post, a coworker inquired, "[i]s this where we can complain about work?"175 The therapist and the coworker then exchanged a few messages discussing how to cope with their boss. ${ }^{176}$ Another therapist reported the Facebook postings to the director. ${ }^{177}$ Due to further complaints about the therapist's performance, the director brought the therapist into his office to discharge her. The conversation began with a discussion of the therapist's Facebook posts; however, the therapist left the meeting before the director could address her performance issues. ${ }^{178}$

The NLRB's Office of the General Counsel concluded that the therapist was not engaged in protected concerted activity; here, the therapist's Facebook posting was merely an expression of an individual gripe about an action by the director that affected only the therapist. ${ }^{179}$ The Office of the General Counsel stated:

The posting contained no language suggesting that she sought to initiate or induce coworkers to engage in group action. And the only co-worker who commented in response to the posting stated that he did not think that the Charging Party's post was an

171. Copiah Bank Adv. Mem., supra note 162 , at $* 2$.

172. Copiah Bank Adv. Mem., supra note 162, at*2.

173. See Advice Memorandum from the NLRB Office of the Gen. Counsel to Wanda Pate Jones, Regional Director of Region 27, Intermountain Specialized Abuse Treatment Center, No. 27-CA-065577, 2011 WL 6543306, at *1 (Dec. 6, 2011) [hereinafter Intermountain Adv. Mem.], available at http://mynlrb.nlrb.gov/link/document.aspx/ 09031d458077b79d.

174. Intermountain Adv. Mem., supra note 173, at *2.

175. Intermountain Adv. Mem., supra note 173, at *3. (internal quotation marks omitted).

176. Intermountain Adv. Mem., supra note 173, at *3.

177. Intermountain Adv. Mem., supra note 173, at*3.

178. Intermountain Adv. Mem., supra note 173, at*3.

179. Intermountain Adv. Mem., supra note 173, at *3. 
attempt to change anything at work. The only other therapist in the office not only did not join in the "discussion" but viewed the posting as inappropriate and reported it to the Director. ${ }^{180}$

Further, the Office of the General Counsel concluded there was ample evidence to support the employer's assertion that it would have discharged the therapist for ongoing performance issues regardless of her Facebook posting. ${ }^{181}$ The Office of the General Counsel also rejected the therapist's claim that the employer had engaged in unlawful surveillance of her Facebook activities, noting there was no evidence that the employer solicited the information; instead, the employer learned about the therapist's Facebook posting from her coworker. ${ }^{182}$

\section{T. Commenting to Former Coworkers}

A hospital nurse who had been transferred from the intensive care unit (ICU) initiated an email exchange through Facebook with a former coworker - who still worked at the hospital in the ICU - in which the nurse made derogatory comments about the ICU supervisor. ${ }^{183}$ The coworker took exception to the nurse's comments and informed the nurse's supervisor about the comments, at which point the nurse was suspended pending an investigation. ${ }^{184}$ One week later, the nurse was fired based on allegations of sexual harassment that arose during the investigation. ${ }^{185}$

At issue was the fact that the discharge occurred close in time to the email exchange with the coworker. ${ }^{186}$ However, the NLRB's Office of the General Counsel concluded the suspension and discharge did not violate section 8(a)(1) because the nurse was not engaged in protected section 7 conduct. ${ }^{187}$ In particular:

The Charging Party's communication with Former Co-worker was not concerted activity for mutual aid and protection, but merely a personal gripe about Charging Party's former supervisors. The communication was not an attempt to initiate group action, and it did not involve a discussion among employees regarding their shared concerns about working

180. Intermountain Adv. Mem., supra note 173, at *3.

181. Intermountain Adv. Mem., supra note 173, at *3.

182. Intermountain Adv. Mem., supra note 173, at*3.

183. See Advice Memorandum from the NLRB Office of the Gen. Counsel to Rochelle Kentov, Regional Director of Region 12, Miami Jewish Health Systems, No. 12-CA-65993, 2011 WL 6960023, *1 (Dec. 14, 2011) [hereinafter Miami Jewish Health Adv. Mem.], available at $\mathrm{http}: / /$ mynlrb.nlrb.gov/link/document.aspx/09031d458079355d.

184. Miami Jewish Health Adv. Mem., supra note 183, at *2.

185. Miami Jewish Health Adv. Mem., supra note 183, at*2.

186. Miami Jewish Health Adv. Mem., supra note 183, at*2.

187. Miami Jewish Health Adv. Mem., supra note 183, at *2. 
conditions; indeed, the only recipient of the emails was Former Co-worker, and she not only did not share Charging Party's concerns but found the emails inappropriate and reported them to her manager. There is no evidence that the Charging Party's statements were a continuation of earlier concerted discussions or other activities. ${ }^{188}$

As such, even if the nurse was discharged as a result of the email messages as opposed to the alleged harassment-which appears to have been the motive for the employer's action - the nurse was not engaged in protected concerted activity. ${ }^{189}$

\section{U. Miscellaneous Social Media Incidents}

On January 24, 2012, the NLRB's Acting General Counsel released a memorandum summarizing fourteen charges "concerning the protected and/or concerted nature of employees' social media postings and the lawfulness of employers' social media policies and rules," which have been presented to the Regional Offices and are then submitted to the NLRB's Division of Advice for consideration by the Office of the General Counsel. ${ }^{190}$ Based on the facts presented in the memorandum, four of the incidents have been the focus of formal Advice Memoranda and have already been discussed. ${ }^{191}$ Of the remaining ten incidents: one involves protected concerted activity subject to an overly-broad social media policy ${ }^{192}$ two involve unprotected activity, but still overly-broad social media policies; ${ }^{193}$ four involve protected concerted activity with no discussion of the employer's social media policy; ${ }^{194}$ and three solely involve discussions of the employer's social media policy. ${ }^{195}$ The seven incidents involving online postings summarized in this latest memorandum are discussed below.

188. Miami Jewish Health Adv. Mem., supra note 183, at*3.

189. Miami Jewish Health Adv. Mem., supra note 183, at*2.

190. Memorandum from Lafe Solomon, Acting Gen. Counsel, NLRB to All Regional Directors, Officers-in-Charge, and Resident Officers, Report of the Acting Gen. Counsel Concerning Social Media Cases, at 2 (Jan. 24, 2012) [hereinafter Acting General Counsel's Memo], available at $\mathrm{http} / / / \mathrm{myn} l \mathrm{rb} . n l \mathrm{rb} . g o v /$ link/document.aspx/09031d45807d6567.

191. See supra Parts II.J., L., M., and P. It can only be presumed that the remaining ten incidents have not been the subject of formal Advice Memoranda, as the employers and Charging Parties are not identified in the Acting General Counsel's Memo.

192. See infra Part II.U.1.

193. See infra Parts II.U.2. and 3.

194. See infra Parts II.U.4., 5., 6., and 7.

195. See Acting General Counsel's Memo, supra note 190, at 13-18; infra Part III.B. (discussing social media policies). 


\section{Posting that Your Employer Had "Messed Up"}

After a collections agency employee was transferred to a position she believed would lead to lower compensation, she posted on her Facebook wall, using expletives, that her employer had "messed up" and "she was done with being a good employee."196 Approximately ten coworkers and the employee's immediate supervisor were among her Facebook friends, and at least two coworkers posted supportive comments, along with a number of former coworkers. ${ }^{197}$ The next day, the employee was fired due to her Facebook comments. ${ }^{198}$ The NRLB's Office of the General Counsel concluded the employer's rule prohibiting "[m]aking disparaging comments about the company through any media, including online blogs, other electronic media or through the media" was unlawful because it would reasonably be construed to restrict section 7 activity-for example, prohibiting statements that the employer was not treating employees fairly or paying them sufficiently. ${ }^{199}$

The General Counsel's office also concluded that the employee was engaged in protected concerted activity: she initiated her Facebook discussion after being transferred to a less-lucrative position; coworkers responded, echoing their frustrations with the employer's treatment of employees; as such, the initial posting and follow-up discussion "clearly involved complaints about working conditions...." 200 The General Counsel's office concluded that the employee was fired in violation of section $8(a)(1)$ because it was done pursuant to an overly broad nondisparagement rule. ${ }^{201}$

\section{Complaining About a Reprimand}

After being reprimanded by a supervisor in front of a Regional Manager for not performing a task she had never been told to perform, an employee of a home-improvement store used her phone during her lunch break to update her Facebook status with a comment that included an expletive with the store's name. ${ }^{202}$ Four individuals, including one coworker, indicated they "Liked" the employee's status comment. ${ }^{203}$ The employee posted another Facebook comment, and had some face-to-face conversations with coworkers about the incident, but the general responses

196. See Acting General Counsel's Memo, supra note 190, at 3.

197. See Acting General Counsel's Memo, supra note 190, at 4.

198. See Acting General Counsel's Memo, supra note 190, at 4.

199. See Acting General Counsel's Memo, supra note 190, at 4.

200. See Acting General Counsel's Memo, supra note 190, at 5.

201. See Acting General Counsel's Memo, supra note 190, at 5.

202. See Acting General Counsel's Memo, supra note 190, at 6.

203. See Acting General Counsel's Memo, supra note 190, at 6. 
of coworkers were limited to sympathy for the employee's plight. ${ }^{204} \mathrm{Six}$ weeks after the original incident, the employee was fired due to her Facebook postings. ${ }^{205}$ Subsequent to the employee's dismissal, the employer issued a new social media policy, providing that, "in external social networking situations, employees should generally avoid identifying themselves as the Employer's employees, unless there was a legitimate business need to do so or when discussing terms and conditions of employment in an appropriate manner." 206

The NLRB's Office of the General Counsel concluded the employee's Facebook posts were not protected because they "were merely an expression of an individual gripe[,]" and because there were no other efforts to induce or prepare for group action. ${ }^{207}$ However, the General Counsel's office took issue with the employer's social media policy-in particular, its restriction to only "appropriate" employment-related discussions. ${ }^{208}$ The policy provided no definition or examples of what would be appropriate or inappropriate discussions; "employees would therefore reasonably interpret the rule to prohibit protected activity, including criticism of the Employer's labor policies, treatment of employees, and terms and conditions of employment."209

\section{Ranting Against Coworkers}

An employee who had become the target of coworkers' insults and threats posted a rant on Facebook against those coworkers and her employer, stating that she hated people at work and wanted to be left alone. ${ }^{210}$ The employee was fired due, in part, to her Facebook posting. ${ }^{211}$ The NLRB's Office of the General Counsel concluded the employee was not engaged in concerted activity because she was expressing personal anger with coworkers and the employer that were made solely on her own. ${ }^{212}$ However, the General Counsel's office concluded that the employer's social media policy, which prohibited employees "from using social media to engage in unprofessional communication that could

204. See Acting General Counsel's Memo, supra note 190, at 6.

205. See Acting General Counsel's Memo, supra note 190, at 7.

206. See Acting General Counsel's Memo, supra note 190, at 7.

207. See Acting General Counsel's Memo, supra note 190, at 7.

208. See Acting General Counsel's Memo, supra note 190, at 7.

209. See Acting General Counsel's Memo, supra note 190, at 8. The General Counsel's Office concluded also that the social media policy's "savings clause" was insufficient to cure the ambiguities within the policy. See Acting General Counsel's Memo, supra note 190 , at 8 .

210. Acting General Counsel's Memo, supra note 190, at 11 .

211. Acting General Counsel's Memo, supra note 190, at 12.

212. Acting General Counsel's Memo, supra note 190, at 12. 
negatively impact the Employer's reputation or interfere with the Employer's mission or unprofessional/inappropriate communication regarding members of the Employer's community," was unlawfully broad in violation of section 8(a)(1) because it would reasonably be construed to chill employees in the exercise of their section 7 rights. ${ }^{213}$

\section{Complaining About Sexist Remarks}

After a male manager remarked to the Charging Party, a female, that he was not surprised she and a fellow female coworker had not been at work the previous day because of a severe snowstorm, and after the Charging Party had not received a response from her supervisor or the HR Assistant to her complaint about what she perceived to be this sexist remark by the manager, she used her cell phone to post a comment on her Facebook page, indicating, with some profanity, that "she did not want to be told that she was less of a person because she was a female."214 This led to a Facebook "conversation" over the next few hours with various friends, only one of whom was a coworker, in which the Charging Party made a number of derogatory remarks about the manager, though without expressly naming him. ${ }^{215}$ A week later, after a coworker was fired (for unrelated activities), the Charging Party posted additional Facebook comments about her work situation. ${ }^{216}$

The Charging Party was an administrative assistant to whom many coworkers would turn to for advice about work problems. ${ }^{217}$ In a meeting with the employer's President following the Facebook postings, the President stated that the Charging Party had previously been warned not to get involved with other employees' problems. The Charging Party was then fired because she "had continued to voice her opinions on Facebook on company time...."218 Here, the NLRB's Office of the General Counsel concluded that the Charging Party had been engaged in protected concerted activity because she often had discussions with fellow employees about terms and conditions of employment, and her Facebook postings "precipitated her discharge because the Employer perceived that she would not comply with his oral warning not to engage in protected conversations

213. Acting General Counsel's Memo, supra note 190, at 12. Although the employee was fired for violating the employer's overly broad social media policy, her discharge did not violate section 8(a)(1) because she was not fired for engaging in concerted activity. Acting General Counsel's Memo, supra note 190, at 12.

214. Acting General Counsel's Memo, supra note 190, at 18.

215. Acting General Counsel's Memo, supra note 190, at 18-19.

216. Acting General Counsel's Memo, supra note 190, at 19.

217. Acting General Counsel's Memo, supra note 190, at 18.

218. Acting General Counsel's Memo, supra note 190, at 19. 
with her fellow employees about their working conditions."219 The General Counsel's office concluded that the Charging Party's discharge was, in essence, a "pre-emptive" strike by the President because of his fear of what the Charging Party's discussions might lead to. ${ }^{220}$

\section{Complaining About a Coworker's Promotion}

After the employer promoted an employee to the position of comanager, the Charging Party posted a message on Facebook reflecting her frustration. ${ }^{221}$ This led to a Facebook "conversation" among the Charging Party and three Facebook coworker friends, which included complaints about the promoted employee and mismanagement. ${ }^{222}$ One of the coworkers commented that, "it would be pretty funny if all of the good employees actually quit." ${ }^{223}$ The Charging Party commented that she had not received a raise or a review in three years. ${ }^{224}$ Of the four workers who participated in the Facebook conversation, two, including the Charging Party, were fired; the other two were disciplined - all due to the Facebook posts. $^{225}$

The NLRB's Office of the General Counsel concluded the four employees were engaged in protected concerted activity; they had discussed their shared concerns about terms and conditions of employment. ${ }^{226}$ While the concerted aspect of their discussions may have been preliminary in nature, the General Counsel's office concluded they had been halted by the employer's pre-emptive discharge and discipline of the four employees. ${ }^{227}$

\section{Stating That You Hate Where You Work}

In February 2011, several employees engaged in a Facebook "conversation" discussing issues at work including postings by the Charging Party which included comments that she hated "that place" and that the Operations Manager was the one "who made it so bad."228 A few

219. Acting General Counsel's Memo, supra note 190, at 20.

220. Acting General Counsel's Memo, supra note 190, at 20.

221. Acting General Counsel's Memo, supra note 190, at 20.

222. Acting General Counsel's Memo, supra note 190, at 21.

223. Acting General Counsel's Memo, supra note 190, at 21.

224. Acting General Counsel's Memo, supra note 190, at 21.

225. Acting General Counsel's Memo, supra note 190, at 21.

226. Acting General Counsel's Memo, supra note 190, at 21 (noting also that prior to the Facebook postings, the Charging Party had spoken to two coworkers on separate occasions over how the employer had selected the employee for promotion).

227. Acting General Counsel's Memo, supra note 190, at 22.

228. Acting General Counsel's Memo, supra note 190, at 23. 
days later the Charging Party was fired due to her Facebook posts. ${ }^{229}$ The NLRB's Office of the General Counsel concluded the Charging Party's Facebook posts constituted protected concerted activity because (1) "employee complaints and criticism about a supervisor's attitude and performance may be protected by the Act," and (2) the Facebook "conversation" was a continuation of earlier group action that included employee complaints to management about the Operations Manager. ${ }^{230}$ In this incident, the General Counsel's office considered whether the Charging Party lost protection because the Facebook "conversation" could be viewed by nonemployee members of the public, possibly harming the employer's reputation and business. ${ }^{231}$ It concluded, however, that the Charging Party did not lose protection of the Act because, while her comments were critical of the Operations Manager, they were not defamatory and were "not in any way critical of the Employer's product or business policies.",232

\section{Making Multiple Accusations Against Your Employer}

A hospital disciplined and ultimately terminated a nurse due to his numerous online postings and public statements, including: repeatedly asserting the hospital's conduct had contributed to a fired employee shooting two supervisors, killing one and critically wounding the other; accusing the hospital of abusing its employees in a letter to the local newspaper; posting online that the hospital had been named in an unfair labor charge; and sending a local newspaper an online letter to the editor critical of the hospital. ${ }^{23}$ The nurse was reprimanded for the last two comments. $^{234}$ The nurse was suspended after another of his letters to the editor was posted on the newspaper's website and he posted a follow-up comment on the newspaper's online forum, claiming that four employees who had "stood up to management... were subjected to abuse and manipulation." 235 Three months later, the nurse made a presentation to the borough assembly, the text of which was posted on the nurse's Facebook page and in the newspaper, charging that "under the leadership of the Employer's CEO, there had been multiple unfair labor practices filed, forced policy changes, a murder/suicide, unfair firings, harassment, and

229. Acting General Counsel's Memo, supra note 190, at 23.

230. Acting General Counsel's Memo, supra note 190, at 23.

231. Acting General Counsel's Memo, supra note 190, at 25.

232. Acting General Counsel's Memo, supra note 190, at 25.

233. Acting General Counsel's Memo, supra note 190, at 26.

234. Acting General Counsel's Memo, supra note 190, at 26-27.

235. Acting General Counsel's Memo, supra note 190, at 27. 
workplace bullying." 236 The nurse was then fired for posting the presentation. ${ }^{237}$

The NLRB's Office of the General Counsel concluded the comments and communications relied upon by the hospital in disciplining and firing the nurse "were related to and in the context of an on-going labor dispute between the employees and their employer." 238 It noted in particular that the nurse's statements were widely followed by fellow employees. ${ }^{239}$ The General Counsel's office concluded also that the nurse's comments did not lose protection of the Act for being disparaging: they "were general criticisms of the Employer's treatment of its employees and their working conditions and were related to and in the context of ongoing labor disputes. Moreover, the criticisms did not disparage the Employer's product: its provision of healthcare. $" 240$

\section{Facebook Posts Containing Racial Stereotypes and Slurs}

After the Charging Party, an employee at the Detroit Medical Center, received a promotion and raise, other employees complained that his promotion and raise violated their collective bargaining agreement, and the Charging Party ultimately lost his promotion and raise for that reason. ${ }^{241}$ In response, the Charging Party posted derogatory comments about his coworkers on his Facebook page that contained racial stereotypes and slurs. $^{242}$ In response to the Facebook comments, the Charging Party's workplace locker was vandalized and he was told to stay at home a few days until the workplace atmosphere cooled. ${ }^{243}$ The Charging Party was disciplined and placed on probation for violating the employer's social media policy. ${ }^{244}$

The NLRB's Office of the General Counsel conceded the Charging Party's Facebook posts could have constituted protected concerted activity since they arguably contained "complaints about his union's performance of its representational duties...."245 The General Counsel's office concluded, however, that the posts lost their section 7 protection because

236. Acting General Counsel's Memo, supra note 190, at 27.

237. Acting General Counsel's Memo, supra note 190, at 27.

238. Acting General Counsel's Memo, supra note 190, at 27.

239. Acting General Counsel's Memo, supra note 190, at 28-29.

240. Acting General Counsel's Memo, supra note 190, at 29.

241. Advice Memorandum from the NLRB Office of the Gen. Counsel to Ray Kassab, Acting Regional Director of Region 7, Detroit Medical Center, No. 07-CA-06682, 2012 WL 1795803, at *1 (Jan. 10, 2012) [hereinafter Detroit Med. Ctr. Adv. Mem.] available at http://mynlrb.nlrb.gov/link/document.aspx/09031d458084ffc5.

242. Detroit Med. Ctr. Adv. Mem., supra note 241, at*1-2.

243. Detroit Med. Ctr. Adv. Mem., supra note 241, at *2.

244. Detroit Med. Ctr. Adv. Mem., supra note 241, at*2.

245. Detroit Med. Ctr. Adv. Mem., supra note 241, at*3. 
the Charging Party's use of offensive racial stereotypes was opprobrious and caused a serious disruption in the workplace.

\section{W. Criticizing Coworkers}

Five employees of Hispanics United of Buffalo, Inc. ("HUB"), a nonprofit corporation which renders social services to its economically disadvantaged clients in Buffalo, New York, engaged in a Facebook "conversation" in which they expressed their concern over being criticized by a particular coworker who was also threatening to complain about their job performances to supervisors. ${ }^{246}$ The target of the criticisms complained to HUB's Executive Director about the Facebook posts and the five employees were subsequently fired. ${ }^{247}$

In determining the firings were an unlawful violation of the NLRA, ${ }^{248}$ the ALJ stated:

The [five fired employees] were taking a first step towards taking group action to defend themselves against the accusations they could reasonably believe [their coworker] was going to make to management. By discharging the ... [employees, HUB] prevented them by [sic] taking any further group action vis-à-vis [the coworker's] criticisms. Moreover, the fact that [HUB] lumped the [employees] together in terminating them, establishes that [HUB] viewed the five as a group and that their activity was concerted. ${ }^{249}$

The ALJ continued:

Just as the protection of Sections 7 and 8 of the Act does not depend on whether organizing activity was ongoing, it does not depend on whether the employees herein had brought their concerns to management before they were fired, or that there is no express evidence that they intended to take further action, or that they were not attempting to change any of their working conditions. $^{250}$

In conclusion, "[e]xplicit or implicit criticism by a co-worker of the manner in which they are performing their jobs is a subject about which employee discussion is protected by Section 7."251

246. Hispanics United of Buffalo, Inc., Docket No. 3-CA-27872, 2011 WL 3894520, at 4-6 (N.L.R.B. Div. of Judges Sept. 2, 2011), available at http://mynlrb.nlrb.gov/link/document.aspx/ 09031d4580622877 (pagination based on NLRB-source document).

247. Id. at 6 .

248. Id. at 7 .

249. Id. at 8-9.

250. Id. at 9 .

251. Id. at 9 . 


\section{Embarrassing Your Employer}

Robert Becker, a salesman with Knauz BMW, was concerned that the dealership was going to serve hot dogs from a hot dog cart and bagged chips at a promotional event celebrating a redesigned BMW model, and posted his concerns on his Facebook page. ${ }^{252}$ The same day, Becker also posted pictures and his own commentary of an incident at a dealership across the street, also owned by the same owner as Knauz BMW, in which a potential customer's teenage son evidently drove a Land Rover into a pond located on the property. ${ }^{253}$ Becker was subsequently fired. ${ }^{254}$

Besides Becker's Facebook post concerning the promotional event, the dealership's salespeople had held in-person discussions about the food to be served at the event, fearing it would hurt sales and, consequently, their commissions. ${ }^{255}$ This, the ALJ concluded, constituted protected concerted activity. ${ }^{256}$ The posting about the Land Rover incident, however, was not protected activity because it "had no connection to any of the employees' terms and conditions of employment." ${ }^{257}$ Because it was the Land Rover posting which was the primary reason Becker was fired, ${ }^{258}$ Becker was not fired in violation of the NLRA. ${ }^{259}$

Although the ALJ did not find that Becker was unlawfully fired, he did conclude that three provisions of the employer's Employee Handbook restricted employees in the exercise of their section 7 rights. ${ }^{260}$ The ALJ paraphrased two of the provisions as "prohibit[ing] employees from participating in interviews with, or answering inquiries concerning employees from, practically anybody." 261 The ALJ concluded that "[i]f employees complied with the dictates of these restrictions, they would not be able to discuss their working conditions with union representatives, lawyers, or Board agents."262 A third Employee Handbook provision stated, "[n]o one should be disrespectful or use profanity or any other language which injures the image or reputation of the Dealership.."263 The

\footnotetext{
252. Karl Knauz Motors, Inc., No. 13-CA-46452, 2011 WL 4499437, at 1-3 (N.L.R.B. Div. of Judges Sept. 28, 2011), available at http://mynlrb.nlrb.gov/link/document.aspx/09031d4580683b21 (pagination based on NLRB-source document).

253. Id. at 4 .

254. Id. at 4-5.

255. Id. at 2 .

256. Id. at 8 .

257. Id. at 9 .

258. Id . at 9 .

259. Id at 9 .

260. Id. at 10-11.

261. Id. at 9 .

262. Id. at 10.

263. Id. at 9 (internal quotation marks omitted).
} 
ALJ concluded employees could reasonably interpret this provision as curtailing their section 7 rights. ${ }^{264}$ Although the dealership had rescinded the provisions in question prior to the ALJ hearing, the ALJ concluded rescission alone was not sufficient - the dealership did not give assurances to employees that in the future it will not interfere with the exercise of their section 7 rights. ${ }^{265}$ The ALJ therefore ordered the dealership to post a notice that it would not interfere with employees in the exercise of their section 7 rights. ${ }^{266}$

\section{Y. Accusing Your Employer of Improperly Withholding Payroll Taxes}

Some of the employees of the Triple Play Sports Bar and Grille ("Triple Play") received an unpleasant surprise when they filed their 2010 state tax returns - they owed the state still more taxes. ${ }^{267}$ In February 2011, a former Triple Play employee posted a message on her Facebook wall about how she owed additional taxes, claiming the owners of Triple Play could not "do the tax paperwork correctly!!!"268 Soon three current employees and two customers joined the "conversation," posting negative comments about Triple Play and its owners, including a suggestion that one of the owners pocketed the unpaid withholding taxes. ${ }^{269}$ The next day, one of the employees who participated in the Facebook conversation-Jillian Sanzone-was fired, in part, because her Facebook comment indicated disloyalty. ${ }^{270}$ Two days after the Facebook conversation, another employee, Vincent Spinella, was also fired. ${ }^{271}$ Spinella had not posted a comment, but had used a Facebook feature to indicate that he "Liked" one part of the conversation. ${ }^{272}$ The owners fired Spinella because by clicking "Like," Spinella did not have Triple Play's best interests in mind. ${ }^{273}$

The ALJ concluded that Sanzone and Spinella were engaged in protected concerted activity when they participated in the Facebook

264. Id. at 11. The ALJ concluded that a fourth provision - " [a] bad attitude creates a difficult working environment and prevents the Dealership from providing quality service to our customers," id. at 9 (internal quotation marks omitted) would reasonably be read to protect the relationship between the dealership and its customers, rather than to restrict the employees' section 7 rights. Id. at 11 .

265. Id. at 11 .

266. Id. at $12,14$.

267. Three D, L.L.C., No. 43-CA-12915, 2012 WL 76862, at 3 (N.L.R.B. Div. of Judges Jan. 3, 2012), available at http://mynlrb.nlrb.gov/link/document.aspx/ 09031d458079eae4 (pagination based on NLRB-source document).

268. Id. at 3 .

269. Id. at 3-4.

270. Id. at 4 .

271. Id. at 5 .

272. Id. at 4 .

273. Id. at 5 . 
conversation: "It is beyond question that issues related to wages, including the tax treatment of earnings, are directly related to the employment relationship ...."274 The Facebook conversation "was part of a sequence of events, including other, face-to-face employee conversations, all concerned with employees' complaints regarding [Triple Play's] tax treatment of their earnings." "275 The ALJ also concluded that Spinella's selecting the "Like" option "was sufficiently meaningful as to rise to the level of concerted activity." 276

\section{Z. Complaining About Late Paychecks}

In August 2010, a number of employees at Bay Sys Technologies, LLC began complaining in Facebook posts about delays in receiving their paychecks, which were republished by a local newspaper. ${ }^{277}$ One of the employees participating in the conversations was subsequently fired. ${ }^{278}$ The NLRB concluded the discharged employee, as well as the other employees, were clearly engaged in protected concerted activity-a conclusion made easier by the fact that the employer did not defend against the charge. ${ }^{279}$

\section{Changes Wrought By Social Media}

Three fundamental issues arise from the incidents discussed above. First, only twelve of the incidents were determined to involve concerted activity, and only ten were protected by the NLRA. ${ }^{280}$ The advent of employee social media postings has not created any new bright-line test for what constitutes protected concerted activity. Second, the NLRB is taking a hard look at employers' social media policies. In particular, an outright ban on disparaging or criticizing the employer risks being considered by the NLRB a violation of section 7. Third, the NLRB is considering the extent to which an employer's access to an employee's Facebook postings constitutes unlawful surveillance. These three considerations are discussed next.

\footnotetext{
274. Id. at 8 .

275. Id. at 8 .

276. Id. at $8-9$

277. Bay Sys Techs., LLC, 357 N.L.R.B. 1 (2011).

278. Id. at 2 .

279. Id.

280. See supra Parts II.B., C., E., U.1., 4., 5., 6., and 7., V., W., Y., and Z. Recall that Kathleen Reichle's Facebook posts complaining about a coworker were not protected because she was not a statutory employee, see supra note 70, and Robert Becker's Facebook post complaining about his employer was not protected since it was not the reason he was fired, see supra notes 252-59.
} 


\section{A. Protected Concerted Activity Revisited}

If anything, the above analysis of the thirty-two incidents - coupled with the fact that nearly sixty percent of the social media charges included in the FOIA request have been closed without further action ${ }^{281}$ - establishes that merely talking about work online does not automatically constitute protected concerted activity. Although the Board has developed a definition of concerted activity, it is subject to interpretation.

As noted earlier, the U.S. Supreme Court applied section 7's concerted activity language in $N L R B$ v. Washington Aluminum Co., holding that employees who walked off the job due to extreme cold in their work area engaged in protected concerted activity. ${ }^{282}$ In reversing the Board's original decision that the employees had engaged in protected concerted activity, ${ }^{283}$ the Fourth Circuit Court of Appeals ruled that since the workers summarily left the workplace in violation of workplace rules without giving the employer an opportunity to address their complaint, their action was not protected by section $7 .^{284}$ The Supreme Court disagreed, holding that employees do not "necessarily lose their right to engage in concerted activities under $\S 7$ merely because they do not present a specific demand upon their employer to remedy a condition they find objectionable."285

But what must be the context of the discussion between or among employees? Shortly after the Supreme Court's Washington Aluminum Co. decision, the Third Circuit Court of Appeals ruled that in order to be protected under section 7, a worker's conversation "must appear at the very least that it was engaged in with the object of initiating or inducing or preparing for group action or that it had some relation to group action in the interest of the employees."286 The courts and the Board further considered

281. The number of social media-related charges identified through the FOIA request are relatively miniscule compared to total charges filed. For example, approximately 23,500 charges were filed with the NLRB in 2010. N.L.R.B., Charges and Complaints, http://www.nlrb.gov/charges-and-complaints (last visited May 26, 2012). However, an argument can be made that rather than being ignorant and fearful of section 7 rights, see Peter D. DeChiara, The Right to Know: An Argument for Informing Employees of Their Rights Under the National Labor Relations Act, 32 HARV. J. ON LEGIS. 431, 458 (1995) ("Most likely, the vast majority of non-union employees remain ignorant of this right, or are too fearful to exercise it.") (footnote omitted), nonunion employees are ignorant of the scope of their section 7 rights.

282. 370 U.S. 9, 14 (1962).

283. Wash. Aluminum Co., 126 N.L.R.B. 1410 (1960), aff'd. 370 U.S. 9 (1962).

284. NLRB v. Wash. Aluminum Co., 291 F.2d 869, 877 (4th Cir. 1961) (“"T] he purpose of the $[\mathrm{A}] \mathrm{ct}$ was not to guarantee to the employees the right to do as they please under any given set of circumstances and in total disregard of the obligations of their employment.").

285. Wash. Aluminum Co., 370 U.S. at 14.

286. Mushroom Transp. Co. v. NLRB, 330 F.2d 683, 685 (3d Cir. 1964).

Activity which consists of mere talk must, in order to be protected, be talk looking toward group action. If its only purpose is to advise an 
the contours of concerted activities in a series of decisions involving a truck driver who was discharged after his safety complaints and his refusal to drive an unsafe truck after reporting its condition to the Tennessee Public Service Commission. ${ }^{287}$ The ALJ had determined the employer violated section 7 by discharging the employee, following an interpretation of concerted activity developed in Alleluia Cushion Co.: despite not involving other workers, an individual employee's safety complaints were of vital interest to coworkers and therefore would be supported by those coworkers. $^{288}$ In Meyers $I$, the Board reversed its earlier approach to concerted activity reflected in Alleluia Cushion Co., noting that the wording of section 7 "demonstrates that the statute envisions 'concerted' action in terms of collective activity: the formation of or assistance to a group, or action as a representative on behalf of a group." 289 It also enunciated a definition of concerted activity: "to find an employee's activity to be 'concerted,' we shall require that it be engaged in with or on the authority of other employees, and not solely by and on behalf of the employee himself., 290

The D.C. Circuit Court of Appeals reversed Meyers I, rejecting both Alleluia Cushion Co., as well as the Board's definition of concerted activity

\footnotetext{
individual as to what he could or should do without involving fellow workers or union representation to protect or improve his own status or working position, it is an individual, not a concerted, activity, and, if it looks forward to no action at all, it is more than likely to be mere

Id. "griping."

287. Meyers Indus., Inc. [Meyers I], 268 N.L.R.B. 493 (1984).
}

288. Alleluia Cushion Co., 221 N.L.R.B. 999, 1000 (1975) ("[W]here an employee speaks up and seeks to enforce statutory provisions relating to occupational safety designed for the benefit of all employees, in the absence of any evidence that fellow employees disavow such representation, we will find an implied consent thereto and deem such activity to be concerted."). This is known as "constructive" concerted activity. See, e.g., Terry A. Bethel, Constructive Concerted Activity Under the NLRA: Conflicting Signals from the Court and the Board, 59 IND. L.J. 583, 584 (1984) (stating that the NLRB has blurred the distinction between individual and concerted action, and even purely individual action that ostensibly benefits the group can be considered concerted action under the constructive concerted activity doctrine). Gorman and Finkin argue that by using the term "concerted activity," Congress never intended to exclude individual action:

In terms of statutory construction, there are not two abstract and distinguishable categories of action-individual action for self-interest and collective action for mutual interest - one which Congress chose not to protect and the other which Congress chose to protect, but rather a continuum of individual activity — of individuals choosing to speak and act on their own behalf, singly and in small and large groups.

Robert A. Gorman \& Matthew W. Finkin, The Individual and the Requirement of “Concert” Under the National Labor Relations Act, 130 U. PA. L. REV. 286, 344-45 (1981).

289. Meyers I, 268 N.L.R.B. at 493-94.

290. Id. at 497 . 
enunciated in Meyers $I^{291}$ Specifically, the circuit court believed the Board incorrectly assumed it was required to narrowly interpret the section 7 statutory language. ${ }^{292}$ In contrast, as noted by the Court of Appeals, the Supreme Court had previously stated:

Although one could interpret the phrase, "to engage in concerted activities," to refer to a situation in which two or more employees are working together at the same time and the same place toward a common goal, the language of section 7 does not confine itself to such a narrow meaning. ${ }^{293}$

Instead, regarding the nature of the relationship that must exist between the action of the individual employee and the actions of the group in order for section 7 to apply, it is for the Board "to resolve in light of its expertise in labor relations, as long as its judgment [is] reasonable." 294

On remand, the Board, while acknowledging its wide latitude in interpreting section $7,{ }^{295}$ concluded its definition enunciated in Meyers I was reasonable. ${ }^{296}$ In addition the Board stated, "[t]here is nothing in the Meyers $I$ definition that states that conduct engaged in by a single employee at one point in time can never constitute concerted activity within the meaning of Section 7."297 For example, the Board explained that the definition "encompasses those circumstances where individual employees seek to initiate or to induce or to prepare for group action, as well as individual employees bringing truly group complaints to the attention of management." 298

Eleven of the thirty-two incidents discussed in this article appear fairly clear-cut. In Reuters, the employee was reprimanded for tweeting a comment regarding union negotiations. ${ }^{299}$ The latest NLRB Acting General Counsel's Memo recounts five incidents in which the General Counsel's

291. Prill v. NLRB, 755 F.2d 941, 950 (D.C. Cir. 1985).

292. Id. at 952 .

293. NLRB v. City Disposal Sys., Inc., 465 U.S. 822, 831 (1984); Prill, 755 F.2d at 951.

294. Prill, 755 F.2d at 951 (citing City Disposal Sys., Inc., 465 U.S. at 829).

295. Meyers, Indus., Inc. [Meyers II], 281 N.L.R.B. 882, 883 (1986) ("At the outset, we reaffirm our recognition that the Board has a wide latitude in interpreting Section 7 of the Act, as the Supreme Court has stated on numerous occasions.").

296. Id. at 885 ("[T] he Meyers I definition strikes a reasonable balance. It is not so broad as to create redundancy in Section 7, but expansive enough to include individual activity that is connected to collective activity, which lies at the core of Section 7.").

297. Id. While Meyers I may have required more explicit authorization of representation of a group, Meyers II implies that express authorization is not a necessary prerequisite. B. Glenn George, Divided We Stand: Concerted Activity and the NLRA, 56 GEO. WASH. L. REV. 509, 517 n.55 (1988). But see Sharpe, supra note 5, at 208 (asserting that after Meyers II the NLRB does not currently recognize as concerted, for example, "a lone employee reporting company safety violations to a state agency").

298. Meyers II, 281 N.L.R.B. at 887.

299. See supra, Part II.C. (providing details of the events that transpired in Reuters). 
office concluded employees were engaged in protected concerted activities. $^{300}$ In Hispanics United of Buffalo, the employees were fired as a result of their online discussions, which were in reaction to a coworker's criticisms of the manner in which the HUB employees performed their jobs. ${ }^{301}$ The fired employees were taking the first steps in group action arising from accusations against them that they believed were going to be presented to management, action they were prevented from completing because they were fired. ${ }^{302}$ In Triple Play Sports Bar and Grille, two employees were fired for "disloyalty" after participating in a Facebook conversation about improper tax withholdings from their paycheckconsidered beyond question by the ALJ as concerted activity. ${ }^{303}$ Similarly the Board also determined that employees discussing late paychecks were clearly engaged in protected concerted activity. ${ }^{304}$ Kathleen Reichle and her fellow nurses were engaged in concerted activity when they discussed another nurse's continual absenteeism. ${ }^{305}$ Finally, Robert Becker's posting constituted concerted activity because it summarized earlier discussions he had with fellow salespeople regarding the possibility of lower commissions. ${ }^{306}$

Dawnmarie Souza's Facebook postings were more similar to Robert Becker's than the employees at HUB. Fellow employees who responded to Souza's postings mainly offered only commiseration; there was no discussion of group action. However, the NLRB's Office of the General Counsel concluded her Facebook postings were protected concerted activity because they were related to an earlier workplace incident with a

300. See supra, Parts U.1., 4., 5., 6., and 7. (citing a variety examples, ranging from assertions of management incompetence to statements that the employees hated where they work, in which an employee's posts on social media sites were considered concerted action because co-workers responded to the posts or engaged the employee in online "conversation").

301. Hispanics United of Buffalo, Inc., No. 3-CA-27872, 2011 WL 3894520, at 8 (N.L.R.B. Div. of Judges Sept. 2, 2011), available at http://mynlrb.nlrb.gov /link/document.aspx/09031d4580622877 (pagination based on NLRB-source document).

302. Id. at $8-9$.

303. Three D, L.L.C., No. 43-CA-12915, 2012 WL 76862 (N.L.R.B. Div. of Judges Jan. 3, 2012), available at http://mynlrb.nlrb.gov/link/document.aspx/09031d458079eae4.

304. See supra Part II.Z. (discussing a Bay Sys Technologies employee who was wrongly fired for complaining about late paychecks on Facebook).

305. See supra Part II.E. (providing extensive discussion of Reichle's case and the position of the Board's General Counsel). However, Reichle's concerted activity was not protected because she was not a statutory employee. See supra note 70 (noting that Reichle was a supervisor and thus not an "employee" under the meaning of the Act).

306. See supra notes 252-256 and accompanying text. However, Becker's concerted activity was not protected since it was not the reason he was fired. See supra notes 257-259. Recall also that in one incident, an employee's Facebook posts were arguably protected under section 7, but that protection was lost due to racial stereotypes and slurs contained in the posts, which caused significant workplace disruption. See supra Part II.V. 
supervisor. The General Counsel's office evidently considered Souza to have been fired for an outburst related to an earlier section 7 activity. ${ }^{307}$ Yet, when Brian Morris, the Wal-Mart employee, made similar Facebook postings following a dispute with his supervisor in response to which he received only supportive comments from coworkers, the General Counsel's office concluded he was not engaged in protected concerted activity. ${ }^{308}$ The only difference between Souza's activity and Morris's appears to be that Morris's postings were not in response to his section 7 rights having been denied by his supervisor.

Ultimately, as the majority of the incidents discussed in this Article demonstrate, merely airing a complaint or griping about an incident at work is not going to be protected. These incidents clearly enumerate the elements currently required to establish protected concerted activity: (1) online postings must relate to terms and conditions of employment; ${ }^{309}$ (2) there must be evidence of concert-i.e., there must be discussions among employees of the posts or coworker responses to the posts; (3) there must be evidence the employee was seeking to induce or prepare for group action; and (4) the posts must reflect an outgrowth of employees' collective concerns. ${ }^{310}$ The last three elements can be rephrased as requiring the employee to express concerns other than his own, with evidence of an intention to instigate group action or bring a group concern to management. ${ }^{311}$

307. AMR Adv. Mem., supra note 23, at 9, n.16 ("It is well established that the protest of supervisory actions is protected conduct under Section 7.") (citing Datwyler Rubber \& Plastics, Inc., 350 N.L.R.B. 669 (2007); Groves Truck \& Trailer, 281 N.L.R.B. 1194 (1986)). The Office of the General Counsel had concluded that Souza's supervisor had violated the NLRA by denying her union representation when she was ordered to write an incident report. See supra note 42 and accompanying text (stating the same as well as noting supervisor's improper threat based on Souza's invocation of her union rights).

308. Wal-Mart Adv. Mem., supra note 94, at *2.

309. The Board can be quite literal in this regard. See, e.g., Orchard Park Health Care Ctr., 341 N.L.R.B. 642, 644 (2004) (deciding that a complaint by two nurses to the state department of health alleging that the nursing home was excessively hot-while concerted - was not protected because the complaint was made on behalf of patient welfare rather than arising from working conditions; specifically, the nurses' ability to deliver patient care); Holling Press, Inc., 343 N.L.R.B. 301, 302 (2004) (deciding that one female worker who sought the assistance of another in her sexual harassment charge against a male supervisor was not engaged in concerted activity because she was looking out only for herself). These cases contribute to former Board Chairwoman Wilma Liebman's concern that in recent years, the Board "has chosen a very confined view of 'concerted activity' for the purpose of 'mutual aid or protection,' as protected by section 7 of the Act." Wilma B. Liebman, Essay, Decline and Disenchantment: Reflections on the Aging of the National Labor Relations Board, 28 BERKELEY J. EMP. \& LAB. L. 569, 583 (2007).

310. See, e.g., Children's Nat'l Med. Ctr. Adv. Mem., supra note 143, at *2 (discussing a case where the Charging Party failed to meet the criteria for concerted action).

311. See Sagepoint Fin. Adv. Mem., supra note 12, at*3 (stating individual activities that are the logical outgrowth of the concerns expressed by the employees collectively are 
As demonstrated above, particularly exemplified by Dawnmarie Souza ${ }^{312}$ employees can be quite disrespectful in their postings about work and supervisors. ${ }^{313}$ As previously discussed, an employee who is engaged in protected concerted activity can, through "opprobrious" conduct, lose the protection of the Act. ${ }^{314}$ Four factors are considered to determine whether the employee will lose protection: "(1) the place of the discussion; ${ }^{315}$ (2) the subject matter of the discussion; (3) the nature of the employee's outburst; and (4) whether the outburst was, in any way, provoked by an employer's unfair labor practice." 316 The Board has determined "that offensive, vulgar, defamatory or opprobrious remarks uttered during the course of protected activities will not remove activities from the Act's

considered concerted)

312. See AMR Adv. Mem., supra note 23 (describing how Souza had referred to her supervisor using a code for psychiatric patients and called him a "dick" and a "scumbag").

313. See also supra note 94 and accompanying text (describing how one Wal-Mart employee began his Facebook post with "Wuck Falmart!"); Three D, LLC, No. 43-CA12915, 2012 WL 76862, at 11 n.6 (N.L.R.B. Div. of Judges Jan. 3, 2012), available at http://mynlrb.nlrb.gov/link/document.aspx/09031d458079eae4 (pagination based on NLRBsource document) (discussing an employee's use of the word "asshole" to describe one of the employer's owners, and participating in a Facebook conversation in which the owner had been referred to as a "shady little man") (internal quotation marks omitted).

314. See supra note 45 and accompanying text (explaining the standard used to determine whether an employee's conduct makes it beyond the protection of the Act). Or, as articulated by William Corbett, "The Board and the courts have developed a common law exception to section 7 protection where the employee engages in bad faith conduct." Corbett, supra note 9, at 283 (citing illegal conduct as one of the exceptions).

315. The key to this first factor is whether the discussion disrupts the workplace. See Three D, LLC, 2012 WL 76862, at 10. In Triple Play Sports Bar and Grille, customers had participated in the Facebook conversation at issue, raising the question of whether the presence of the customers harmed the business. Id. However, "the presence of customers during brief episodes of impulsive behavior in the midst of otherwise protected activity is insufficient to remove the activity from the ambit of Section 7's protection where there is no evidence of disruption to the customers." Id. (citing LaGuardia Associates, LLP, d/b/a Crowne Plaza LaGuardia, 357 N.L.R.B. No. 95, at 4 (2011); Goya Foods of Fla., 347 N.L.R.B. 1118, 1134 (2006), enforced sub nom. NLRB v. Goya Foods of Fla., 525 F.3d 1117 (11th Cir. 2008)).

316. Atlantic Steel Co., 245 N.L.R.B. 814, 816 (1979). The four factors are generally referred to as the "Atlantic Steel factors." In Souza's case, her comments: took place outside the workplace during non-work hours, addressed supervisory actions, contained no verbal or physical threats, and were provoked by unlawful behavior by her supervisor. See supra note 47 and accompanying text; see also Reef Indus., Inc. v. NLRB, 952 F.2d 830, 837-39 (5th Cir. 1991) (holding that an employee's sending a sarcastic letter and t-shirt to his manager ridiculing the education level of plant employees was protected activity because: statements on the tee-shirt and in the letter were not "fraught with malice, obscene, violent, extreme, or wholly unjustified[;]" the activity was not highly egregious, or ultimately highly harmful to the employer's business; the activity related to an on-going labor dispute and adequately related to the employee's employment relationship; the employee essentially intended to convey his dismay with how the employer treated its employees; and because his activity related to terms and conditions of employment). 
protection unless they are so flagrant, violent, or extreme as to render the individual unfit for further service." ${ }^{317}$ But these exceptions may not be as extreme as indicated. ${ }^{318}$

For example, in the fall of 2008, Nick Aguirre, a newly-hired car salesman, repeatedly questioned his managers and the employer's owner about the size of his commissions, the lack of minimum-wage draws against commissions, and general working conditions. ${ }^{319}$ The managers' usual response was that if Aguirre did not like the situation he should quit. ${ }^{320}$ Aguirre's complaints ultimately led to a meeting among Aguirre, the employer's owner, and its two managers, during which Aguirre lost his temper, berated one of the managers with a string of expletives, stood up, pushed his chair aside, and told the owner that if he fired him, the owner would regret it; at which point the owner then fired Aguirre. ${ }^{321}$ The ALJ found that the employer:

had violated section 8(a)(1) several times by inviting Aguirre to quit in response to his protected protests of working conditions. As to the discharge, however, the ALJ applied Atlantic Steel and concluded that, although Aguirre was engaged in protected activity during the ... meeting, his obscene remarks and personal attacks on [the owner] cost him the Act's protection. ${ }^{322}$

The Board, however, concluded Aguirre's conduct was not so severe as to cause him to lose statutory protection. ${ }^{32}$

The Ninth Circuit Court of Appeals walked through the Atlantic Steel factors to determine whether Aguirre's conduct removed him from NLRA protection. The place of the discussion favored continued protection because it was in a manager's office, away from the workplace and it did

317. Dreis \& Krump Mfg., Inc., 221 N.L.R.B. 309, 315 (1975) (citing Am. Tel. \& Tel. Co., 211 N.L.R.B. 782 (1974); Bob Henry Dodge Inc., 203 N.L.R.B. 78 (1973); Ben Pekin Corp., 181 N.L.R.B. 1025 (1970); Linn v. United Plant Guard Workers, 383 U.S. 53 (1966)); see also Harris Corp., 269 N.L.R.B. 733, 738-39 (1984) (holding that while an employee's letter to management was "harsh, insubordinate, and attacked the personal characters of members of ... management" and was "written in a boorish, ill-bred, and hostile tone[,]" it did not maliciously interfere with the exercise of the employer's rights, the employee did not engage in a clearly deliberate or malicious falsehood, and the employee did not use language which was worse than "unkind and mannerless") (footnote omitted).

318. See Honda of Am. Mfg., Inc., 334 N.L.R.B. 746, 749 (2001) (deciding self-made newsletters employee distributed within the workplace which insinuated another employee was homosexual and used an obscene play on words to refer to the employer's bonus program were "so offensive as to render the otherwise protected newsletters unprotected" under section 7).

319. Plaza Auto Ctr., Inc. v. NLRB, 664 F.3d 286, 289-90 (9th Cir. 2011).

320. Id.

321. Id. at 290-91.

322. Id. at 291

323. Id. 
not affect employee discipline. ${ }^{324}$ The subject matter of the discussion also favored continued protection because it concerned working conditions and Aguirre's outburst was contemporaneous to the nature of the discussion. ${ }^{325}$ Regarding the nature of the outburst, however, the court noted the Board's own precedents, which recognize that an employee's offensive and personally denigrating remarks alone can result in loss of protection. ${ }^{326}$ The court therefore remanded the matter to the Board "to allow it to properly consider whether the nature of Aguirre's outburst caused him to forfeit his protection." ${ }^{\text {227 }}$ Finally, the court agreed that Aguirre's outburst was provoked by the employer's unfair labor practices. ${ }^{328}$ In sum, there is the possibility that regardless of the other three Allied Steel factors, a vitriolic, obscenity-laden outburst could alone deprive an employee of section 7 protection. ${ }^{329}$ In contrast, however, opprobrious comments in the form of racial stereotypes and slurs that cause significant workplace disruption can also deprive an employee of section 7 protection. ${ }^{330}$

Ultimately, the Board and the courts must balance the interests of the employer against the section 7 rights of the employee. ${ }^{331}$ As with Souza,

324. Id. at 292 (rejecting also the employer's contention that protection should be lost because Aguirre requested the meeting with the intent of humiliating the owner in front of his two managers).

325. Id. at 293 .

326. Id. at 293-94 (citing Care Initiatives, Inc., 321 N.L.R.B. 144, 151 (1996); Stanford N.Y. L.L.C., 344 N.L.R.B. 558, 559 (2005); Daimler Chrysler Corp., 344 N.L.R.B. 1324, 1328-29(2005)).

327. Id. at 294-95 (citing Trus Joist MacMillan, 341 N.L.R.B. 369, 371-72 (2004) (concluding that the third Atlantic Steel factor alone may carry enough weight to forfeit the Act's protection)).

328. Id. at 295 (concluding Aguirre's outburst was contemporaneous with both the owner's censure of Aguirre's protected activities and his unfair labor practice of suggesting that Aguirre could work elsewhere if he did not like the company's policies).

329. But see Datwyler Rubber \& Plastics, Inc., 350 N.L.R.B. 669, 670 n.5 (2007) (agreeing in the finding that an employee's outburst was not so opprobrious as to lose the protection of the Act, since even "assuming arguendo the third factor (the nature of the outburst) weighs against protection, it is outweighed by the other three factors").

330. See supra Part II.V.

331. See Corbett, supra note 9, at 283. Also, in balancing the interests of the employer and the rights of the employee, protected activity can lose its protection if it extends beyond a reasonable time. See, e.g., Quietflex Mfg. Co., 344 N.L.R.B. 1055, 1058-59 (2005) (holding "that employees are entitled to persist in their protest for a reasonable period of time, after which the employer is entitled to assert its rights as to its entire premises[;]" and finding that the twelve-hour duration of the employees' action was unreasonable, particularly in view of the employer's attempts to respond to their concerns); see generally Sam Heldman \& Hilary E. Ball, Quietflex Manufacturing and the Unpredictable Case-byCase Balancing of Section 7 Rights: "Liberty Finds no Refuge in a Jurisprudence of Doubt," 22 LAB. LAW. 97 (2006) (critiquing the "Quietflex rule" as not changing the law but raising doubt as to what the law is); Amy J. Zdravecky, "If I Only 'Had a Brain'. . . I Could Figure Out the Contours of Concerted Activity Versus Other Competing Rights": Quietflex Manufacturing and Its Ten-Factor Balancing Act for Determining How Long a Protected 
though, that balance will almost always fall in favor of the employee with the acknowledgement that "time outside working hours, whether before or after work, or during luncheon or rest periods, is an employee's time to use as he wishes without unreasonable restraint...."332 However, outside conduct does not automatically retain section 7 protection that may otherwise be present. For example, posting on Facebook, regarding recent earthquakes in the area, the employee's desire for the employer's building to collapse while certain members of management were inside of the building will generally exempt an employee from section 7 protection. ${ }^{333}$

In addition to illegal activity, deliberate lies will usually take an employee outside of protection. ${ }^{334}$ As discussed earlier, the NLRB's Office of the General Counsel concluded an employee's Facebook post suggesting her employer was engaged in fraud was not protected once the employee refused to remove the post after being informed of convincing evidence that fraudulent conduct had not occurred. ${ }^{335}$

\section{B. Social Media Policies}

As discussed previously, social media policies which may reasonably be interpreted to chill protected concerted activity will be considered unlawful. ${ }^{336}$ While an outright ban on section 7 activities would clearly violate section $8(\mathrm{a})(1),{ }^{337}$ it is not always clear which types of prohibited

Concerted Work Stoppage Can Continue on the Employer's Premises, 22 LAB. LAw. 69 (2006) (discussing the ten circumstances that will determine at what point a protected concerted work stoppage becomes unreasonable so as to lose its protection under the NLRA).

332. Republic Aviation Corp. v. NLRB, 324 U.S. 793, 803 n.10 (1945) (quoting Peyton Packing Co., 49 N.L.R.B. 828, 843 (1943)); see Morris, supra note 10, at 1708.

333. See Dismissal of Charges Letter from Ronald Hooks, Reg'l Dir., NLRB, No. 26CA-24000 (June 30, 2011), available at http://mynlrb.nlrb.gov/link/document.aspx /09031d4580520e25 (discussing dismissal of charges); see also supra Part II.V. (describing loss of section 7 protection due to posting comments containing racial stereotypes and slurs that caused significant workplace disruption).

334. See, e.g., NLRB v. N.Y. Univ. Med. Ctr., 702 F.2d 284, 291 (2d Cir. 1983) (explaining that "[e]rroneous assertions lose their protected status only when they are published with knowledge of their falsity or with reckless disregard of whether they were true or false.") (internal quotation marks omitted) (citing Linn v. United Plant Guard Workers, Local 114, 383 U.S. 53, 65 (1966) (applying specifically to employee protected activity under section 7)).

335. See supra Part II.Q.; see also, United Cable Tel. Corp., 92 Lab. Arb. (BNA) 3, 9 (1998) (Koven, Arb.) (determining that an employee who posted a letter on a union bulletin board which called the employer's vice president a liar did not engage in protected concerted activity because his motive was to "revivify and exacerbate the antagonism that had previously been the controlling feature of the relationship" between the employer and the union prior to a "détente").

336. See supra note 71 and accompanying text.

337. See, e.g., Flagler Hosp. Adv. Mem., supra note 68, at *2 (explaining that "a rule is 
communications may or may not chill section 7 activities. For example, banning disparagement alone does not necessarily restrict section 7 activity. ${ }^{338}$ As noted by the General Counsel's office, "cases in which rules could not reasonably be construed to cover protected activity involved situations in which the rules clarified their scope by including examples of clearly illegal or unprotected conduct and/or there was no evidence that the rules were applied against protected activity." ${ }^{339}$ For example, in Fiesta Hotel Corp., a rule forbidding employees from engaging in "any type of conduct, which is or has the effect of being injurious, offensive, threatening, intimidating, coercing, or interfering with fellow Team Members or patrons" 340 was found not to be unlawful because the prohibited conduct was not "inherently entwined with Section 7 activity[,]" nor was its "terms so amorphous that reasonable employees would be incapable of grasping the expectation that they comport themselves with general notions of civility and decorum in the workplace." ${ }^{\text {341 }}$ Similarly, in an Advice Memorandum, the Office of the General Counsel concluded that Sears Holdings' social media policy, which included a prohibition against "[d]isparagement of company's or competitors' products, services, executive leadership, employees, strategy, and business prospects[,]"342 was not unlawful because the policy itself "covers a list of proscribed activities,

unlawful if it explicitly restricts Section 7 activities").

338. See, e.g., Flagler Hosp. Adv. Mem., supra note 68, at *2 (noting that a rule can implicitly restrict section 7 activities if one of three conditions is met: "(1) employees would reasonably construe the language to prohibit Section 7 activity; (2) the rule was promulgated in response to union activity; or (3) the rule has been applied to restrict the exercise of Section 7 rights") (citing Lutheran Heritage Vill.-Livonia, 343 N.L.R.B. 646, 647 (2004)).

339. Flagler Hosp. Adv. Mem., supra note 68, at*3; see also Acting General Counsel's Adv. Mem., supra note 190, at 17 (concluding that an employer's social media policy that required employees to confine their social networking to matters unrelated to the company was lawful because the overall context, including specific examples listed by the employer, would reasonably be construed by employees to address only communications that could implicate securities regulations).

340. Fiesta Hotel Corp., 344 N.L.R.B. 1363, 1367 (2005) (internal quotation marks omitted).

341. Id. at 1368. But see Hills \& Dales General Hosp., No. 07-CA-53556, 2012 WL 542765 (N.L.R.B. Div. of Judges Feb. 17, 2012), available at http://mynlrb.nlrb.gov/link/document.aspx/09031d4580854c07 (concluding that Values and Standards of Behavior policies which prohibited negative comments about fellow employees, including managers, and engaging in or listening to negativity or gossip were overly broad as they could reasonable be construed as prohibiting protected activity; while a policy that requested employees to represent the employer in the community in a positive and professional manner was not considered unlawful).

342. Advice Memorandum from the NLRB Office of the Gen. Counsel to Martin O. Osthus, Regional Director of Region 18, Sears Holdings (Roebucks), No. 18-CA-19081, 2009 WL 5593880, at *2 (Dec. 4, 2009) [hereinafter Sears Adv. Mem.], available at http://mynlrb.nlrb.gov/link/document.aspx/09031d45802d802f. 
the vast majority of which are clearly not protected by Section 7." ${ }^{343}$ As such, taken as a whole, as in Tradesmen International, the Policy contains sufficient examples and explanation of purpose for a reasonable employee to understand that it prohibits the online sharing of confidential intellectual property or egregiously inappropriate language and not section 7 protected complaints about the Employer or working conditions. ${ }^{344}$ In contrast, AMR's Blogging and Internet Posting policy, which stated that "[e]mployees are prohibited from making disparaging, discriminatory or defamatory comments when discussing the Company or the employee's superiors, co-workers and/or competitors, ${ }^{, 345}$ was considered unlawful because it contained "no limiting language to inform employees that it [did] not apply to Section 7 activity." 346

When the NLRB's Office of the General Counsel or an ALJ has found potentially protected concerted activity, they are much more inclined to address social media policies, versus policies in place when no concerted activity is involved. In Flagler Hospital, where the Charging Party evidently engaged in protected concerted activity but for her status as a supervisor, ${ }^{347}$ the General Counsel's office recommended the NLRB Regional Office issue a complaint arising from the Hospital's social media policy. ${ }^{348}$ In Karl Knauz Motors, Inc., in which Robert Becker engaged in concerted activity but was not dismissed because of that activity, ${ }^{349}$ the ALJ found portions of the employer's social media policy to be unlawful and ordered remedial action - even though the employer had rescinded those policies prior to the ALJ hearing. ${ }^{350}$ In the incident involving the employee

343. Sears Adv. Mem., supra note 342, at*3.

344. Sears Adv. Mem., supra note 342 , at *3. But see William R. Corbett, The Narrowing of the National Labor Relations Act: Maintaining Workplace Decorum and Avoiding Liability, 27 BerKeley J. EMP. \& LAB. L. 23, 47 (2006) (reviewing Board decisions applying workplace rules of decorum and civility, concluding that the Board is narrowing employees' section 7 rights, particularly for nonunion employees).

345. AMR Adv. Mem., supra note 23, at 5.

346. AMR Adv. Mem. supra note 23, at 14. But see Three D, LLC, No. 43-CA-12915, 2012 WL 76862, at 20 (N.L.R.B. Div. of Judges Jan. 3, 2012), available at http://mynlrb.nlrb.gov/link/document.aspx/09031d458079eae4 (pagination based on NLRBsource document) (concluding that an employer's Internet/Blogging Policy-which stated that "employees may be 'subject to disciplinary action' for 'engaging in inappropriate discussions about the company, management, and/or co-workers""-was not unlawful because it was directed toward maintaining the company's reputation with respect to the general public) (citing Tradesmen Int'1, 338 N.L.R.B. 460, 460-61 (2002); Ark Las Vegas Rest. Corp., 335 N.L.R.B. 1284, 1291-92 (2001); Flamingo Hilton-Laughlin, 330 N.L.R.B. 287, 288-89 (1999)).

347. See supra note 70.

348. Flagler Hosp. Adv. Mem., supra note 68, at*3.

349. See supra Part II.X.

350. See supra notes 260-266 and accompanying text. 
who used an obscenity as his job title in a LinkedIn profile, ${ }^{351}$ the NLRB's Office of the General Counsel addressed the employer's electronic Communications Usage policy, which:

forbids material that is "obscene[,] defamatory, harassing or abusive" to any person or entity associated with the company. We note that the inclusion of the word "harassing" arguably could be construed to preclude protected online content, since such a broad term would commonly apply to protected criticism of the employer's labor policies, and the Board has consistently stated that discipline imposed under an unlawfully overbroad rule violates the Act. ${ }^{352}$

However, since the LinkedIn "joke" was not considered concerted, there was no violation of the NLRA when the employee was fired for violating the policy. ${ }^{353}$

The Board has recently formally articulated its stance on overbroad rules:

[D]iscipline imposed pursuant to an unlawfully overbroad rule violates the Act in those situations in which an employee violated the rule by (1) engaging in protected conduct or (2) engaging in conduct that otherwise implicates the concerns underlying Section 7 of the Act. Nevertheless, an employer will avoid liability for discipline imposed pursuant to an overbroad rule if it can establish that the employee's conduct actually interfered with the employee's own work or that of other employees or otherwise actually interfered with the employer's operations, and that the interference, rather than the violation of the rule, was the reason for the discipline. ${ }^{354}$

In other words, if an employee is disciplined for engaging in protected concerted activity through a social media policy containing one or more overbroad rules, the Board will take action against the employer based on its policy. ${ }^{355}$ If an employee is disciplined for engaging in unprotected concerted activity through a social media policy containing one or more overbroad rules, the Board will still take action against the employer based on its policy in order to minimize the chilling effect of the policy. ${ }^{356}$ Finally, if an employee is disciplined for engaging in activity outside the gambit of section 7-fundamentally unconcerted activity - through a social

351. See supra Part II.N.

352. Schulte, Roth \& Zabel Adv. Mem., supra note 130, at *1 n.1.

353. Schulte, Roth \& Zabel Adv. Mem., supra note 130, at*1.

354. Cont'l Grp., Inc., 357 N.L.R.B. No. 39, 2011 WL 3510489, at *6 (Aug. 11, 2011)

("It is the employer's burden... to establish that the employee's interference with production or operations was the actual reason for the discipline.").

355. See, e.g., supra Part II.B.

356. See, e.g., supra Part II.X.; see also notes 76-77 and accompanying text.. 
media policy containing one or more overbroad rules, the Board will not take action against the employer based on its policy as long as the employer can establish the employee's conduct interfered with the workplace and the employee was not disciplined solely because of the overbroad policy. ${ }^{357}$

In the Board's opinion, this approach minimizes the likelihood of a chilling effect on employees' section 7 rights by properly acknowledging the employer's legitimate interests while simultaneously discouraging posthoc rationalization of disciplinary decisions. ${ }^{358}$ Once again, the Board is "balancing... employees' Section 7 rights and employers' legitimate interest in establishing work rules for the purpose maintaining discipline and production." 359

One final aspect of communications policies is that the Board will evidently not consider informal policies unlawful. For example, Brian Pedersen, the Arizona Daily Star reporter, was verbally instructed to not air his grievances or comment about the employer-newspaper in any public forum, ${ }^{360}$ and ultimately told not to tweet about anything work-related. ${ }^{361}$ The NLRB's Office of the General Counsel concluded "those statements did not constitute orally-promulgated, overbroad 'rules[;]' ... the statements were made solely to the Charging Party in the context of discipline, and in response to specific inappropriate conduct, and were not communicated to any other employees or proclaimed as new 'rules."

357. See, e.g., supra Parts II.K. and N.; see generally supra Part II.D.

358. See Cont'l Grp., Inc., 357 N.L.R.B. at *6 (concluding that the rule formulated in the holding "reflects a deliberate balancing of employees' Section 7 rights and employers' legitimate interest in establishing work rules for the purpose [of] maintaining discipline and production").

359. Id.; see supra note 331 and accompanying text (noting that the court may balance the interests of the employer and the rights of the employee). But see Corbett, supra note 344, at 47 (concluding that recent Board decisions have "elevate[d] employers' desires to avoid liability under other laws and to ensure civility and decorum in the workplace and subordinate[d] the rights of workers to engage in protected concerted activity for mutual aid or protection").

360. See supra note 62 and accompanying text.

361. Daily Star Adv. Mem., supra note 59, at *5.

362. Daily Star Adv. Mem., supra note 59, at *7; see also Salon/Spa at Boro, Inc., No. 9-CA-45349, 2010 WL 5099879, at 24 (N.L.R.B. Div. of Judges Oct. 18, 2010), available at http://mynlrb.nlrb.gov/link/document.aspx/09031d45803b97a9 (finding that an older employer's verbal warnings to younger employees not to post comments critical of the business on Facebook to be less about the work environment and more about "life in general") (internal quotation marks omitted) (pagination based on NLRB-source document). It is clear to me that [the employer's] overall purpose in warning her employees to be careful in their use of social networking media was didactic, not coercive. Thus, her references to the potential negative effects of the exercise of poor judgment when using the sites did not represent a threat of reprisal from management but rather a warning that poorly chosen statements or photographs could have a negative impact on a young person's reputation with resulting impact on her career. 


\section{Unlawful Surveillance}

As noted in a few of the incidents described in Part II., employees have accused their employers of unlawful surveillance. ${ }^{363}$ In particular, does a supervisor's knowledge of the contents of an employee's Facebook postings create an impression of surveillance? As a general matter, absent a legitimate justification, employers are prohibited from engaging in surveillance, as it tends to chill employees' freedom to exercise their rights under the NLRA. ${ }^{364}$ This includes surveillance of protected activity taking place during non-work time. ${ }^{365}$ Although discussing union activities, the Board has ruled that "the test for determining whether an employer has created an impression of surveillance is whether the employee would reasonably assume from the statement that their union activities had been placed under surveillance." 366 The Board explained:

The idea behind finding "an impression of surveillance" as a violation of Section $8(a)(1)$ of the Act is that employees should be free to participate in union organizing campaigns without the fear that members of management are peering over their shoulders, taking note of who is involved in union activities, and in what particular ways. ${ }^{367}$

Id. On May 30, 2012, the NLRB's Acting General Counsel released a report in which his office reviewed seven employer social media policies, finding six of them to be unlawful. Memorandum from Lafe Solomon, Acting Gen. Counsel, NLRB to All Regional Directors, Officers-in-Charge, and Resident Officers, Report of the Acting General Counsel Concerning Social Media Cases (May 30, 2012), available at http://mynlrb.nlrb.gov/link/document.aspx/09031d4580a375cd. This latest report provides further guidance from the office of the General Counsel on what is and is not permissible in social media policies.

363. See supra Parts II.A., J., and S. (discussing examples of the application the elements of unlawful surveillance in nonunion settings).

364. See Calif. Acrylic Indus., Inc. v. NLRB, 150 F.3d 1095, 1099 (9th Cir. 1998) (holding that employers violate section 8(a)(1) if employers engage in activities that chill their employees' freedom to exercise section 7 rights); Konop v. Hawaiian Airlines, Inc., 302 F.3d 868, 884 (9th Cir. 2002) (determining that employer surveillance often causes employees to refrain from exercising their rights under federal labor law due to a fear of reprisal).

365. Charles B. Craver, Privacy Issues Affecting Employers, Employees, and Labor Organizations, 66 LA. L. REV. 1057, 1068 (2006).

366. Flexsteel Indus., Inc., 311 N.L.R.B. 257, 257 (1993).

367. Id. In an unreported decision, the Board determined there was no unlawful surveillance when a supervisor viewed a picture of employee union organizers on a union website, considering it analogous to "merely observing open union activity." Magna Int'l, Inc., No. 7-CA-43093(1), 2001 WL 1603861 (N.L.R.B. Mar. 9, 2001). However, when the supervisor mentioned to one of the employees that he had seen her in the picture, "he was conveying the impression that he was keeping track of her union activities and thus was creating the impression of surveillance" in violation of section $8(\mathrm{a})(1)$. Id. (citing Fred'k Wallace \& Sons, Inc., 331 N.L.R.B. 914, 915 (2000) (deciding that "unlawful impression of 
Stated another way, an employer can create an unlawful impression of surveillance when it "reveals specific information about protected activity that is not generally known and does not reveal its source."368 However, Facebook itself can add an extra dimension to this analysis. For example, in Public Service Credit Union, the employer's HR Vice President, who obtained a copy of the Charging Party's Facebook posts, did not reveal which employee was his source. ${ }^{369}$ However, the NLRB's Office of the General Counsel concluded the employer did not engage in unlawful surveillance because the Charging Party had restricted access to his posts to only his Facebook "friends;" therefore, "he could not have reasonably concluded that the Employer was directly monitoring his Facebook page[,]" and could only conclude "that the Employer learned of his Facebook activity from his Facebook friends." ${ }^{, 370}$

There is no impression of surveillance when the employer informs employees it has obtained the content of online postings and conversations from coworkers or customers, ${ }^{371}$ or when the employee has "invited" a supervisor to view Facebook postings by "friending" the supervisor. ${ }^{372}$ Depending on one's Facebook privacy settings, however, friends of friends may be able to see one's postings - so a supervisor may be able to see an employee's postings even if the employee did not "friend" the supervisor, if the supervisor has friended a friend of the employee. Arguably, the knowledge that a supervisor is Facebook friends with some employees

surveillance" was not created by supervisors merely observing union activities, but by supervisors making clear to an employee they were taking particular note of them); Flexsteel Indus., Inc., 311 N.L.R.B. at 257) (noting that an employer may create an impression of surveillance, which constitutes an unlawful interference with section 7 rights)). As revealed in the earlier discussion of incidents, the elements for unlawful surveillance have been applied in nonunion settings. See supra Parts II.A., J., and S. (discussing examples of the application of the elements of unlawful surveillance in nonunion settings).

368. Intermountain Adv. Mem., supra note 173, at *5.

369. Public Service Credit Union Adv. Mem., supra note 137, at *4.

370. Public Service Credit Union Adv. Mem., supra note 137, at *4. (internal quotation marks omitted). See also MONOC Adv. Mem., supra note 31, at *6 (concluding that accepting information from one employee regarding the online activity of another employee does not constitute monitoring); Frontier Tel. of Rochester, Inc., 344 N.L.R.B. 1270, 1276 (2005), enforced sub nom. Frontier Tel. of Rochester, Inc. v. NLRB, 181 F. App'x 85 (2d Cir. 2006) (determining that the employer did not engage in unlawful surveillance by not revealing who had sent copies of postings on a secure website because "a reasonable employee would assume that [the employer] lawfully learned of [his] message exactly the way [the employer] did - through public dissemination by another website subscriber").

371. See MONOC Adv. Mem., supra note 31, at *3 (" $[\mathrm{N}]$ o impression of surveillance is created where the employer explains that it obtained the information from another employees, particularly in the absence of evidence that the employer solicited the information.").

372. See supra note 110 and accompanying text (noting that because the employee "friended" his supervisor, the supervisor could not be said to have engaged in surveillance). 
could chill work-related discussions on Facebook. Like Facebook, Twitter tweets will be public unless the user expressly selects to "protect" her tweets. ${ }^{373}$ If a Twitter user keeps her tweets public, she will not know who is "following" her-in other words, receiving a copy of her tweets - unless she actively manages her account by identifying followers and potentially blocking them from receiving her tweets. Without diligence, a Twitter user could therefore be sending tweets to management without even knowing it - just as a Facebook user's posts may be available to a manager who is a friend of a friend. These are issues raised by newer technology that have yet to be directly addressed by the Board. ${ }^{374}$

What is unknown is whether the Board would consider a manager's access to Facebook posts through friend-of-a-friend status to be equivalent to the Charging Party's Facebook friend giving copies of the posts to the manager. Though, arguably, friend-of-a-friend status implies monitoring, whereas monitoring is generally considered absent when the employer has received copies of Facebook posts by an employee's Facebook friend. Similarly, will a tweeting employee have an obligation to monitor followers to weed out management? Again, electing to follow an employee's tweets implies monitoring. Friend-of-a-friend status or following tweets implies the employer is not merely observing employee activities, but making particular note of them. ${ }^{375}$

Ultimately, is the best advice to employees to limit Facebook posts to friends only and to not make tweets public - fundamentally crippling the social attributes that have made Facebook and Twitter so popular and so dear to their hundreds of millions of users? In the alternative, if employees choose to not heavily restrict access to their posts and tweets, are they then allowing their protected activities to be potentially chilled $?^{376}$ The balance between these two options has yet to be resolved.

373. About Public and Protected Tweets, TwITTER.COM, https://support.twitter.com/ articles/14016-about-public-and-protected-tweets (last visited May 26, 2012).

374. See generally, Jeffery M. Hirsch, The Silicon Bullet: Will the Internet Kill the NLRA?, 76 GEO. WASH. L. REV. 262 (2008) (arguing that the Board's failure to adapt to evolving communications technologies, including the Internet, could result in the NLRA losing its relevancy).

375. See generally, supra note 367 (noting that unlawful surveillance may occur in a nonunion setting, which would include Facebook or twitter surveillance).

376. See generally, Jeffery M. Hirsch, Communication Breakdown: Reviving the Role of Discourse in the Regulation of Employee Collective Action, 44 U.C. DAVIS L. REV. 1091 (2011) (addressing the potential of communications technologies, which could facilitate and enhance concerted activities, to actually thwart such activities, from the perspective of workplace communications in light of the Board's decision in The Guard Publ'g Co., 351 N.L.R.B. 1110 (2007), enforced in part, enforcement denied in part, 571 F.3d 53 (D.C. Cir. 2009)). 


\section{CONCLUDING ANALYSIS}

As the above discussion implies, the fact that employees are using Facebook and other social media tools to discuss work does not alter the basic analysis of what does and does not constitute protected concerted activity. If the majority of social media-related NLRB charges filed by employees against their employers are any indication, most work-related online postings are merely gripes. They are complaints about fellow workers or managers that do not involve a call to action; they do not express a collective concern that has been or will soon be brought to the attention of management. In the alternative, if employee online posts do constitute concerted activity, they will not lose their protection merely because they are rude or disrespectful. They will not lose protection unless they are extremely vitriolic, threaten harm, or otherwise disrupt the workplace.

In the meantime, employers are learning that overly broad social media bans can run afoul of the NLRA. While employers can risk maintaining overly broad policies as long as they respect employee section 7 rights, the Board will take action if it appears an employee was dismissed through such a policy after engaging in concerted activity, protected or not. So far, the main focus has been on policies that ban disparagement of the employer's business or its managers, as often complaining about working conditions can result in disparaging remarks. As such, the NLRB has clearly signaled that without specificity-making clear that concerted activities are not included - an employer's policy against disparagement may be unlawful. The NLRB has also made clear that a "savings clause"an overly broad prohibition ending with a disclaimer it will not be applied against concerted activities — will not save the employer. ${ }^{377}$

Finally, the unique sharing aspects of social media-particularly Facebook - can raise surveillance issues that have yet to be directly addressed by the Board. It is clear that no impression of unlawful surveillance is created when the employer is provided copies of an employee's Facebook posts or tweets by a friend or follower of the employee. And, at least initially, to "Friend" a supervisor on Facebook is tantamount to inviting the supervisor to view the employee's posts. But how voluntary would such a "Friend" request be? Would it be reasonable for the employee to be concerned there could be negative repercussions, however indirect, if the employee refused a supervisor's friend request or later "unfriended" the supervisor? ${ }^{378}$ Similarly, without taking affirmative

377. See, e.g., supra note 82 and accompany text, and note 209.

378. See, e.g., Pietrylo v. Hillstone Rest. Grp., No. 06-5754 (FSH), 2008 WL 6085437, at $* 1$ (D.N.J. July 25, 2008) (involving a restaurant waitress who provided access information to management for a secure MySpace account not because she was "explicitly 
steps to restrict access to Facebook posts or Twitter tweets, there is always the possibility of a friend-of-a-friend or following supervisor lurking in cyberspace. Clearly, supervisors who, through their own efforts, gain access to posts and tweets to potentially track employee communications raise the specter of chilling concerted activities through unlawful surveillance.

threatened with any adverse employment action," but because she was afraid she would get in trouble with management if she did not). 